\title{
المدة في عقد العمل بين قواعد واحكام القانون المدني وقانون العمل العراقيين دراسة مقارنة
} أ. م. د. وَّرَان عبدالقادر دزميى

قسم القانون ، كلية القانون و العلاقات الدولية ، الجامعة اللبنانية الفرنسية ، أربيل ، إقليم كردستان ، العراق

\section{المستخخص}

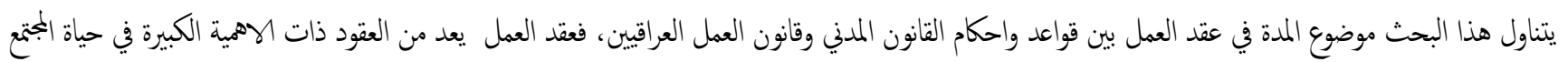

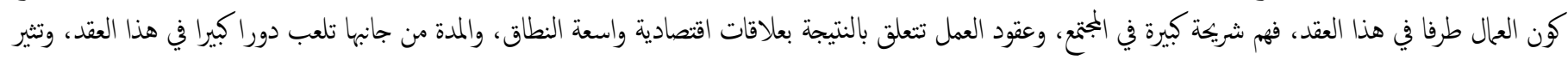

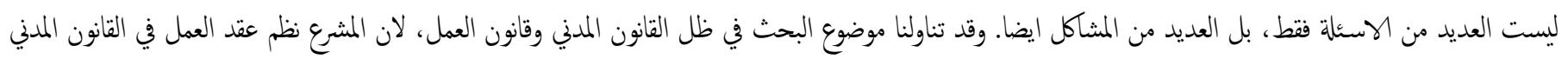

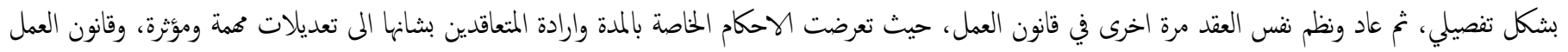

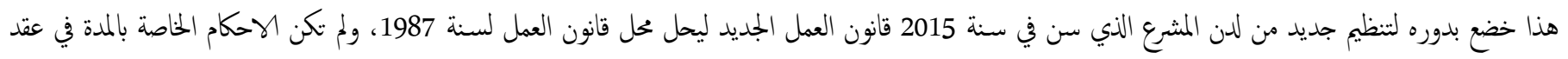

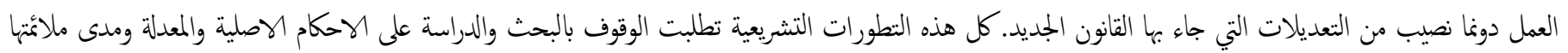

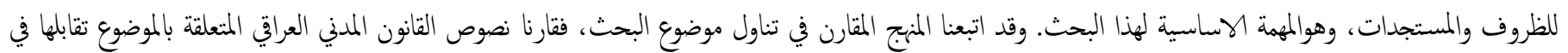

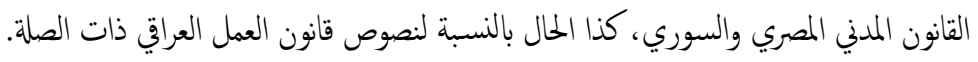

مفاتيح الكلمات: عقد العمل، مدة العقد، العقد محددة المدة، العقد غير محددة المدة، دور الارادة.

القانون المدني الذي خصص الفصل الثاني منه لعقد العمل من المادة 902 ولغاية

1

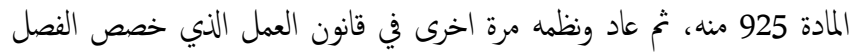

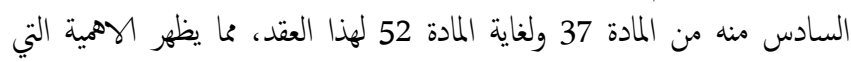

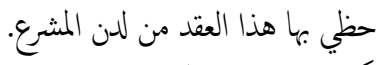

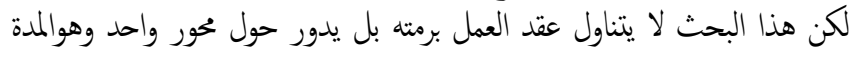

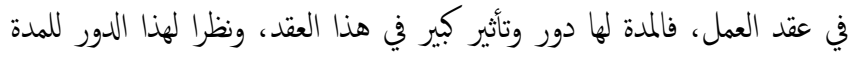

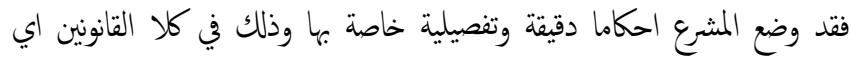

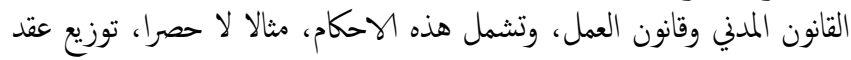




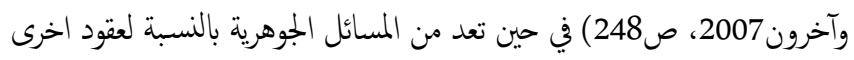

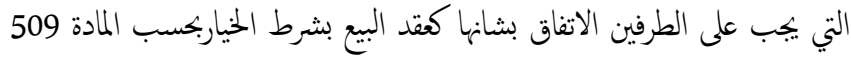

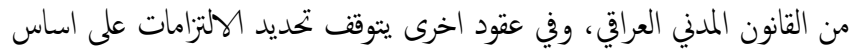

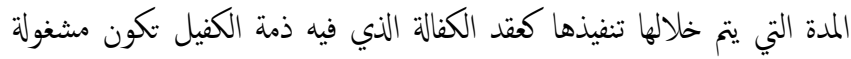

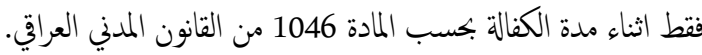

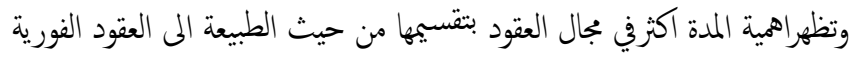

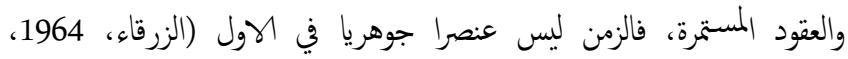

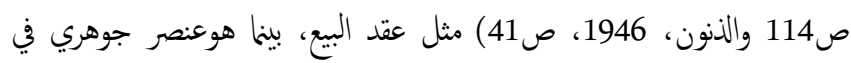

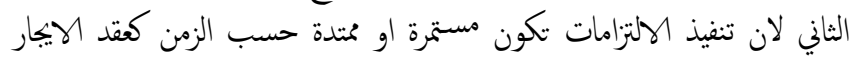

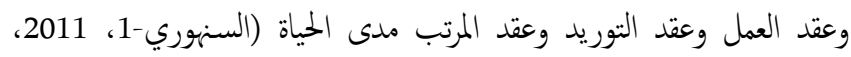

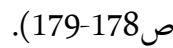
وفي عقد العمل فان دورالمدة هو اكبرلانها تعد ركنا فيه وعلى اساسها يتم تحديد

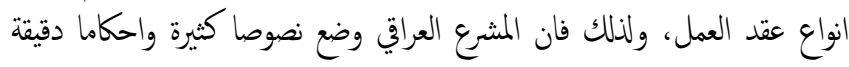
وتفصيلية في القانون المدني خاصة بها.

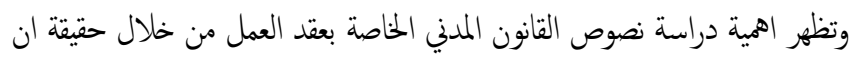

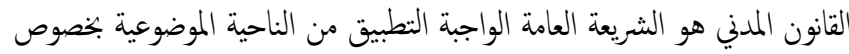

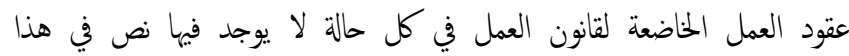
الاخير (كيرة ، ص743).

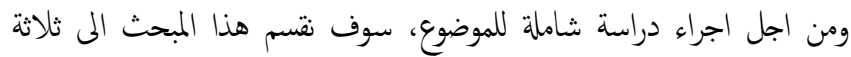

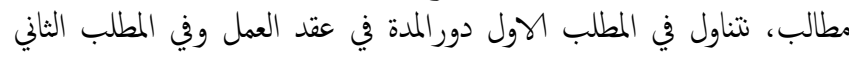

انواع عقد العمل من حيث المدة وفي المطلب الثالث احكام مدة عقد العمل.

\subsection{3 المطلب الاول- دور المدة في عقد العمل}

لقد نظم المثرع العراقي عقد العمل في القانون المدني، باعتباره احد العقود المساة،

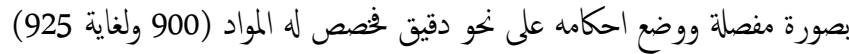
من القانون المذكور، فنتاوله في الفصل الثاني من الباب الثالث الثان المعنون (العقود

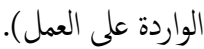
وقد عرف المشرع العراقي عقد العمل في المادة (1/900) من القانون المدني بانه:

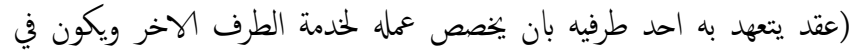

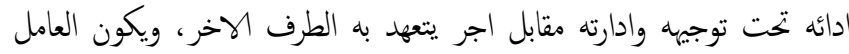

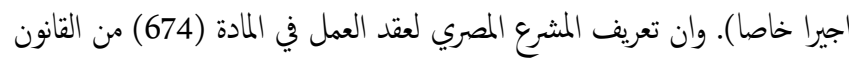

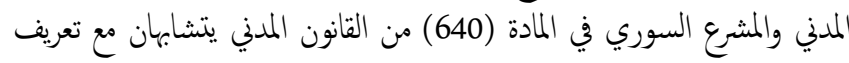
المثرع العراقي من حيث المضمون.

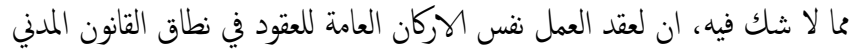

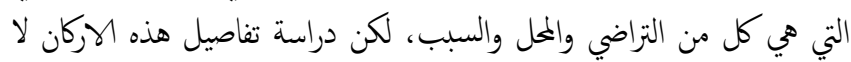

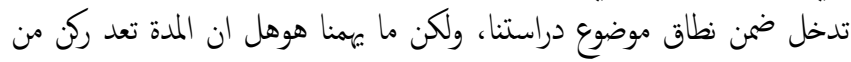

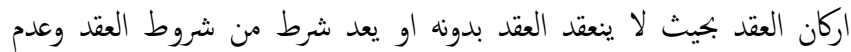
وجوده لا يؤثرعلى وجود العقد.

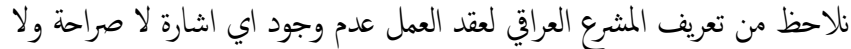

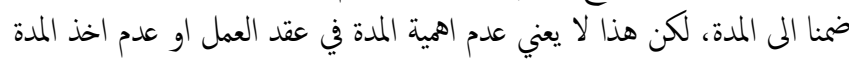

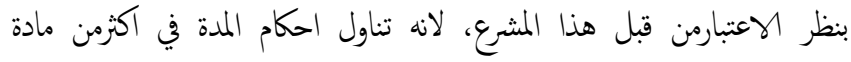

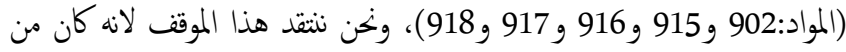

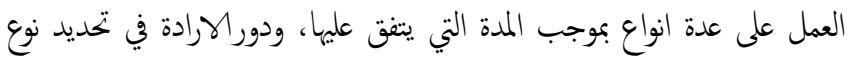

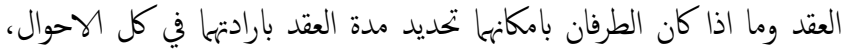

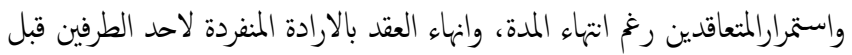

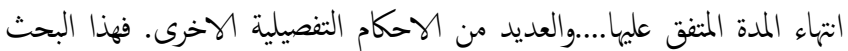

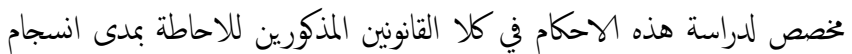

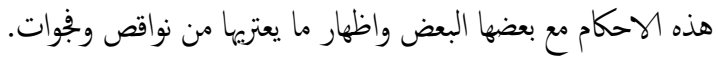

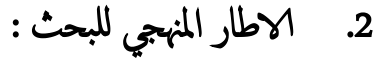

\section{1}

ان تناول المثرع لعقد العمل في قانوين على التوالي يظهربحد ذاته تغيرا في توجه المبه

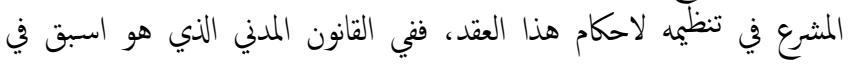

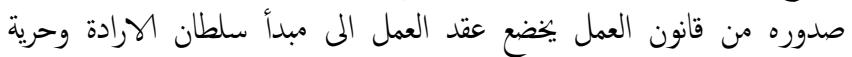

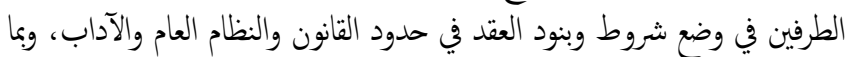

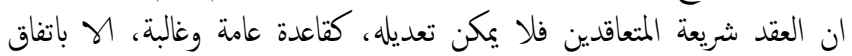

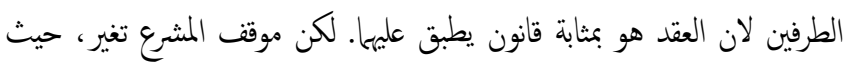

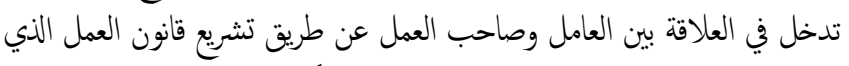
خصص فصلا مستقلا لعقد العمل، حيث عدل الكثير من الاحمكام المتعلقة بهذا

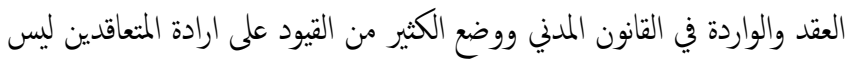

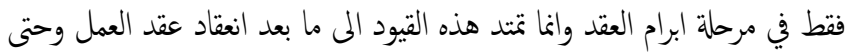

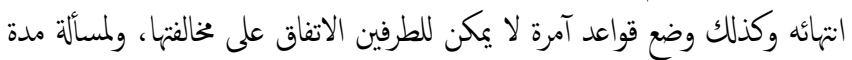

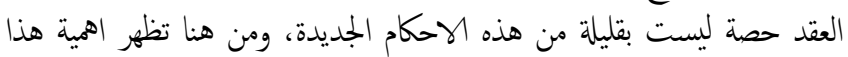
البحث وسبب اختيار هذا الموضوع، اذ من الضروري جدا العادة التفكير في هذه الهاه

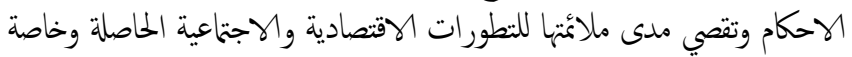

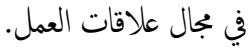

\section{2}

وقد اتبعنا المنهج المقارن في تناول موضوع البحث، فقارنا نصوص القانون المدني

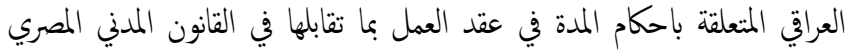

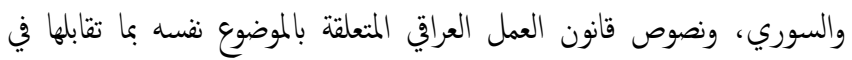
قانون العمل المصري والسوري والجزائري.

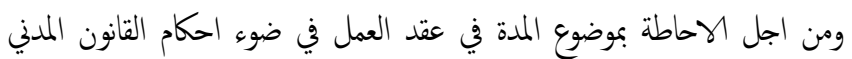

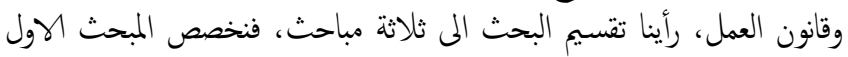

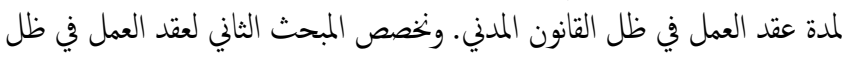

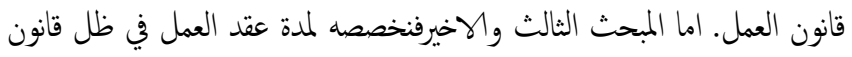

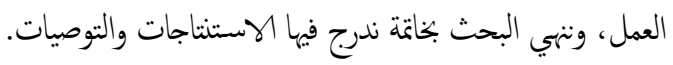

\section{3. المبحث الاول- مدة عقد العمل في ظل القانون المدني}

ان المدة تلعب دورا كبيرا في نطاق القانون المدني وخاصة في مجال العقود. لكن

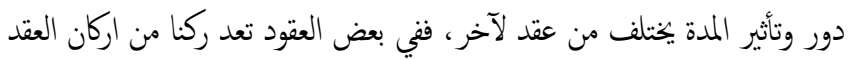

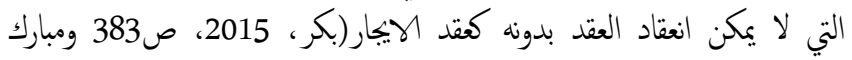




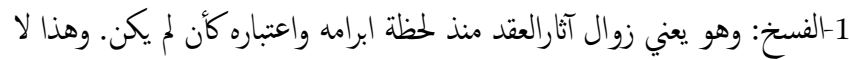

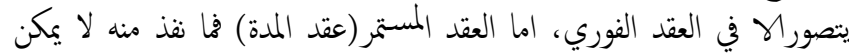

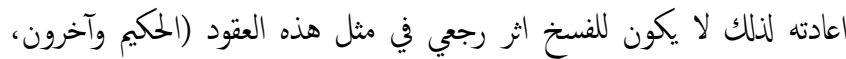

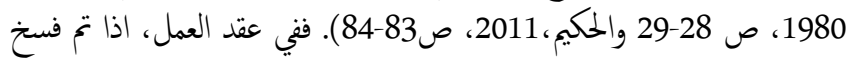

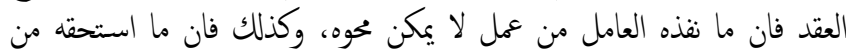

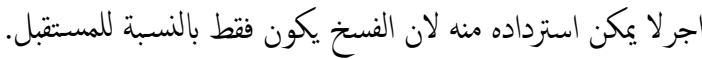

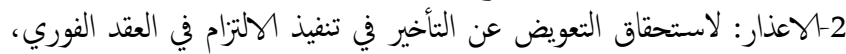

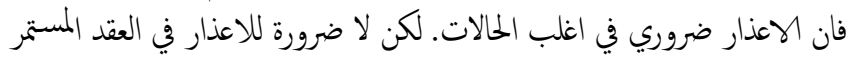

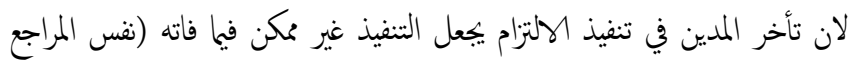

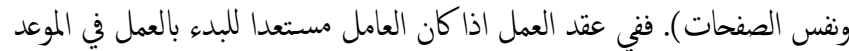

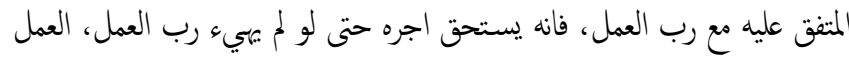

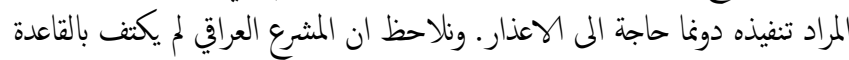

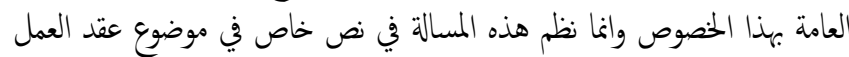
وذلك في المادة (914) من القانون المدني العراقي.

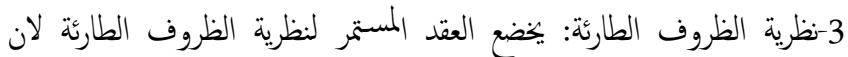

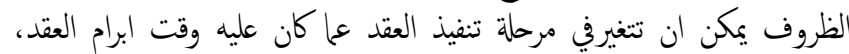

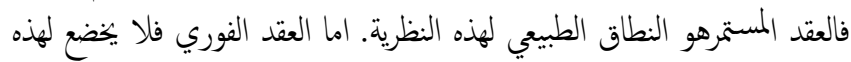

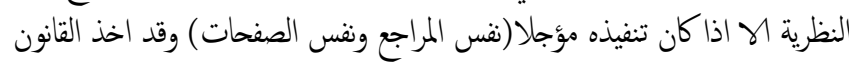

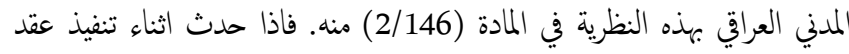

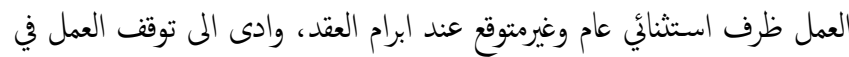

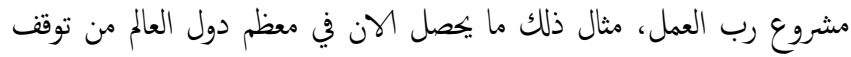

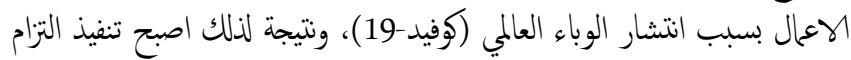

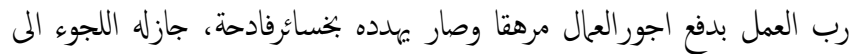
الحمكة، ولمجكمة ان ترفع الارهاق وتنقص الالتزام الى الحد المعتول.

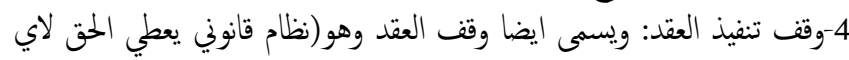

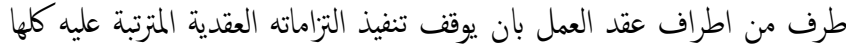

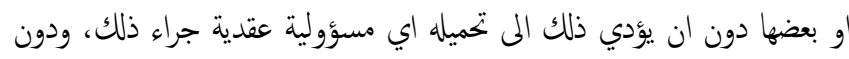

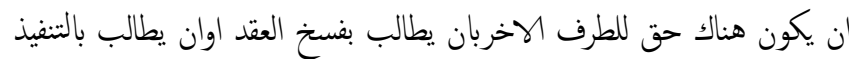

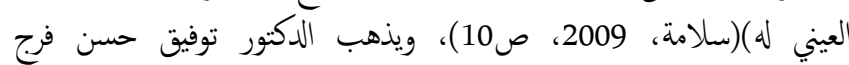

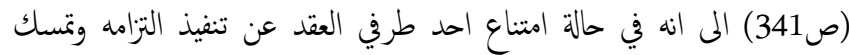

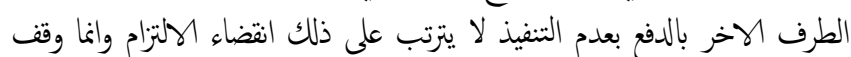

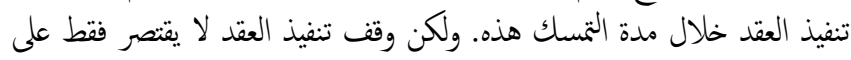

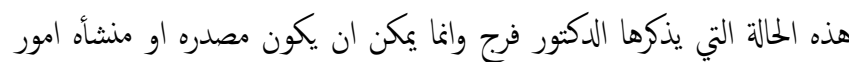

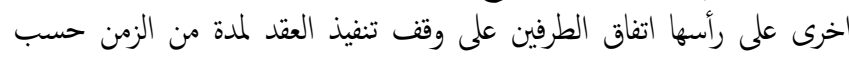

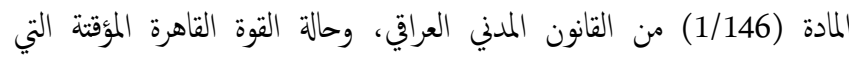

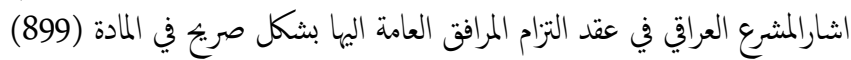

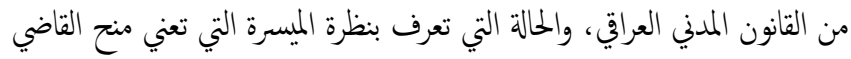

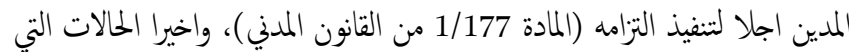

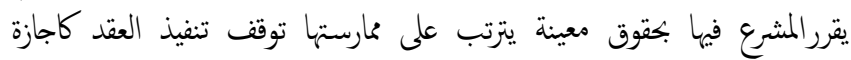

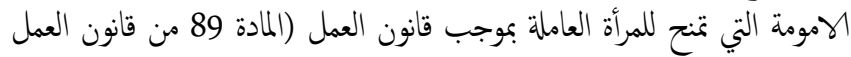

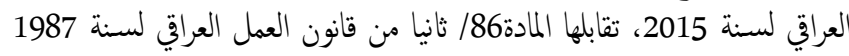

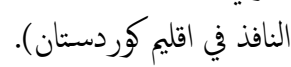

الافضل الاشارة الى المدة اثناء تعريفه لعقد العمل اسوة بما فعل اثناء تعريفه لعقود

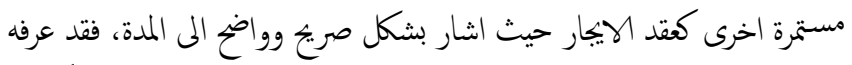

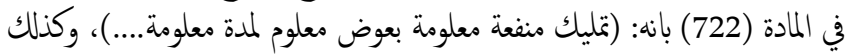

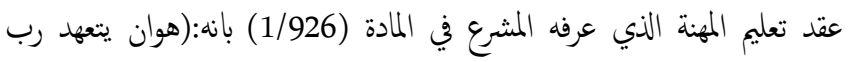

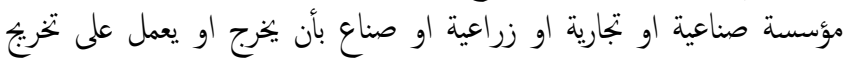

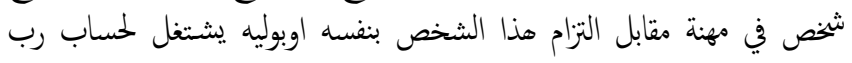

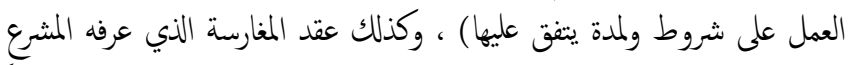

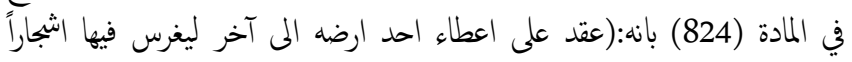
معلومة ويتعهد بترتيبها مدة معلومة.....). فرغ عدم الاشارة هذه، فانا زرى بان المدة في عقد العمل تعد ركنا من اركانه اضافة الى الاركان العامة الاخرى لسببين:

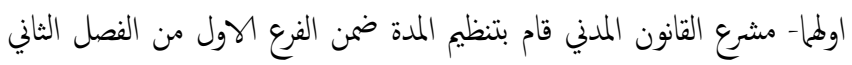

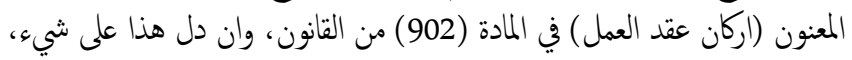

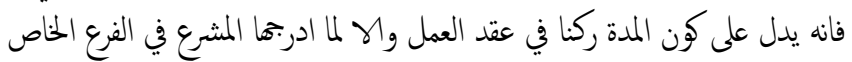
باركان العقد.

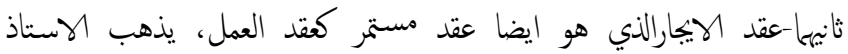

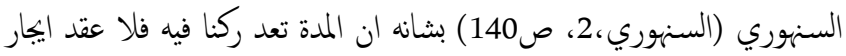

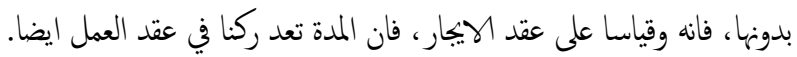

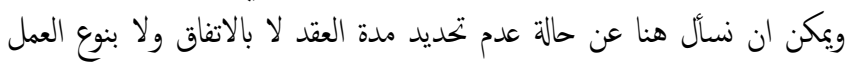
وتأثير ذلك على صحة العقد؟ ان المشرع المدني قد عاج هذه المسألة بنص صرئ فئ في المادة (917) من القانون

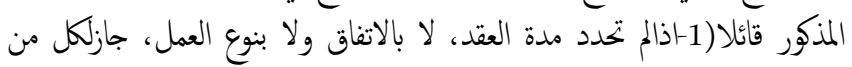

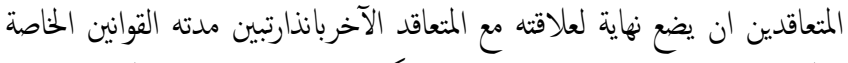

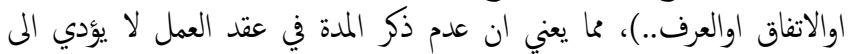

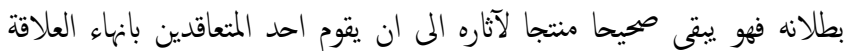
القانونية مع الاخر بعد انذاره. وموققت المشرع هذا يتاشى مع السياسة التشريعية الهادفة الى تقليل حالات التان

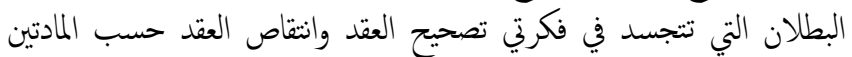

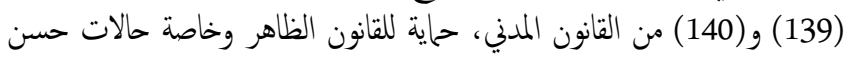

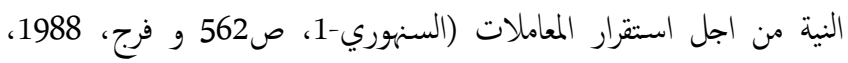

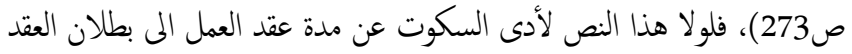

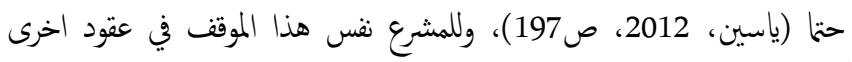

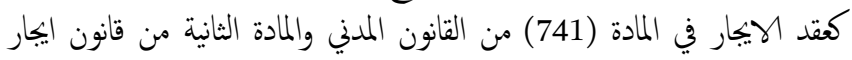

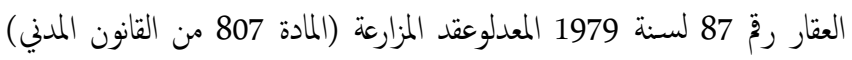

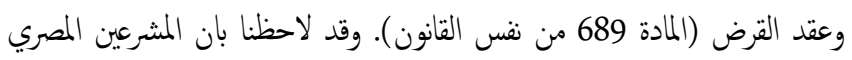

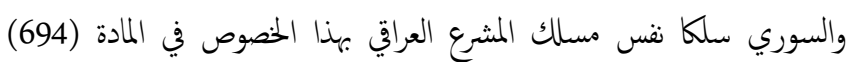

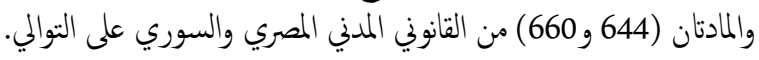

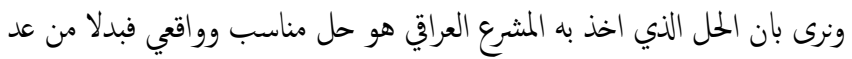

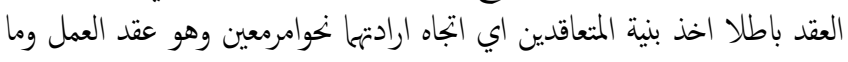

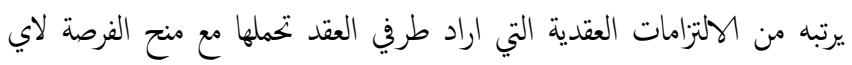

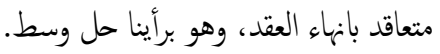
اما الآثار بمتربة على كون المدة ركنا في عقد العمل فهي تظهر في الحلاتات الآتية: 
ان النوع السابق يوفر للمتعاقدين حرية اكثرعلى حساب مبدأ استقرار المعاملات،

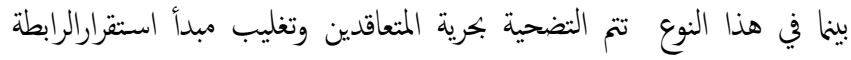
العقدية، لذلك تتجه القوانين الحديثة الى تغليب الرابطة العقدية واضفاء عدم

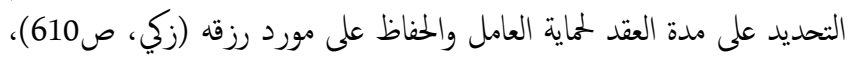

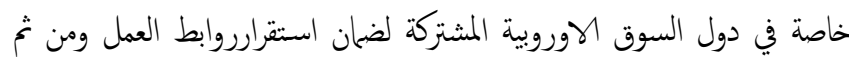

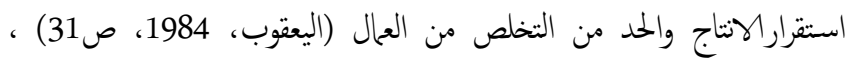

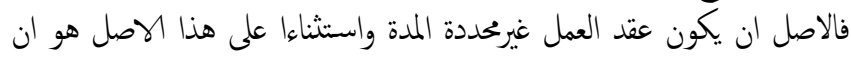

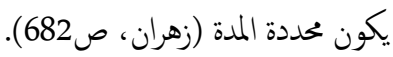

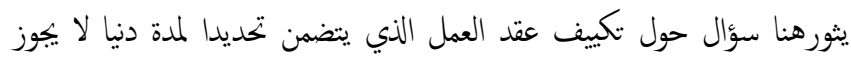
انهاء العقد خلالها من جانب الطرفين، ليسترد في نهاية هذه المدة كل مل من الطن الطرفين حقه في انهاء هذا العقد؟ الهن ذهب اتجاه الى عده عقد عمل محددة المدة خلال المداه المدة المقررة لاستمراره، ويصبح

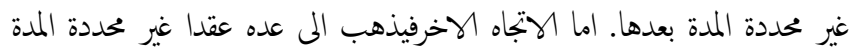

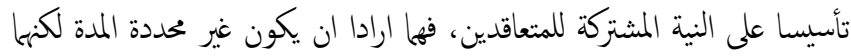

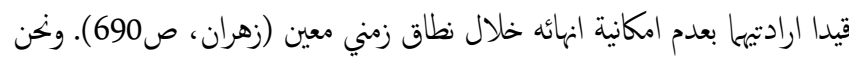

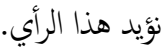

\subsection{3 ثالثاسعقد عمل لخدمة معينة :}

يعني الاتفاق على ان ينتهي العقد بانتهاء العامل من تنفيذ العمل المتفق عليه، كأن

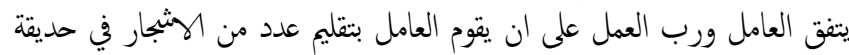

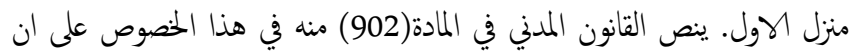

(1) يجيوز ان يبرم عقد العمل لخدمة معينة......).

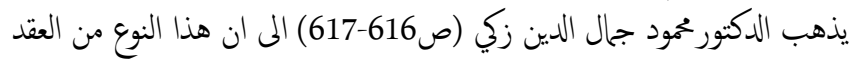

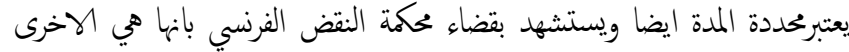

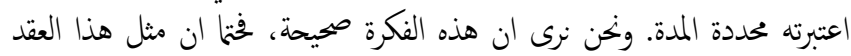

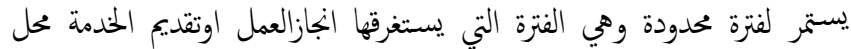

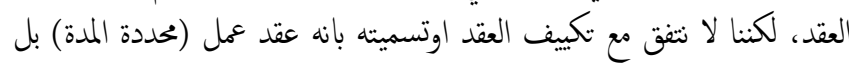

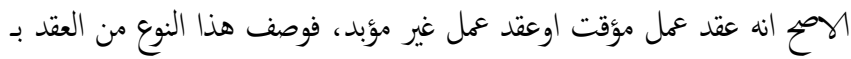

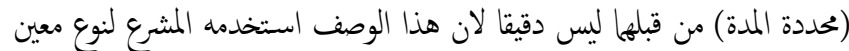
من عقد العمل وهو الذي ينتهي في اجل معين يتفق عليه الطرفان كما راينا اعلاه.

\subsection{4 رابعا-عقد عمل مدة حياة العامل :}

هوالاتفاق على بقاء العقد طيلة حياة العامل، حيث جاء في القانون المدني:(2-واذا

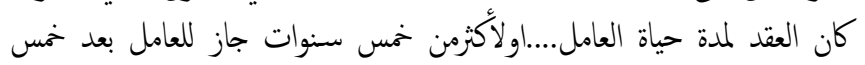
سنوات ان يفسخ العقد دون تعويض على ان ينظررب العمل الى ستة اثشر ).

\subsection{5 خامسا-عقد عمل مدة حياة رب العمل:}

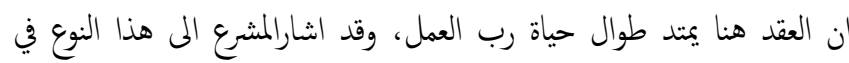

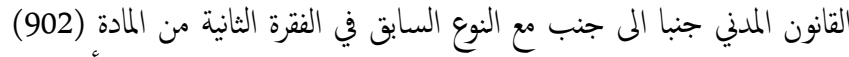

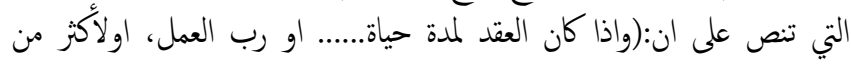

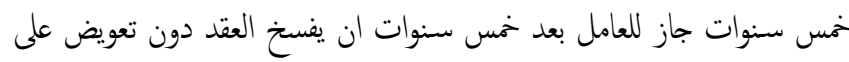
ان ينظررب العمل الم ستة اشهر ).
ففي العقد الفوري لا يؤثروقف تنفيذ العقد على كمية التزامات المتعاقدين فتبقى كما

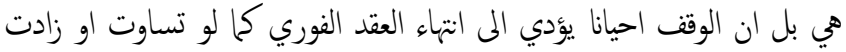

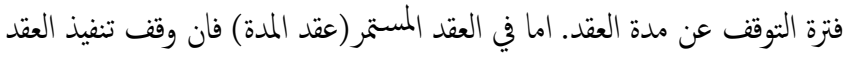

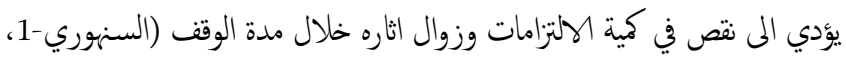

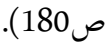
ففي عقد العمل يحق للعامل ورب العمل الاتفاق على ايقاف تنفيذ التزاماتها لفتزة

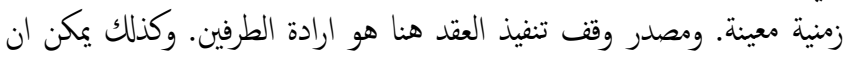

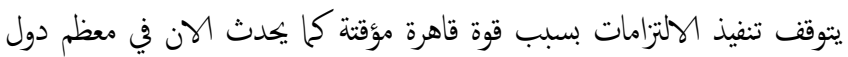

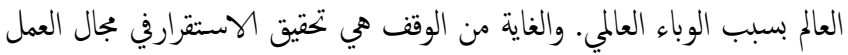

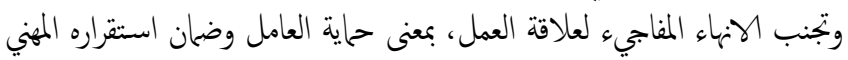
في حالة ظهورظروف معينة تؤدي الى عدم تنفيذ عقد العمل (سلامة،

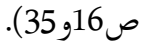

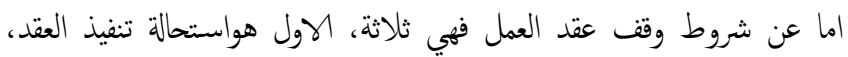

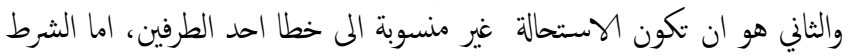

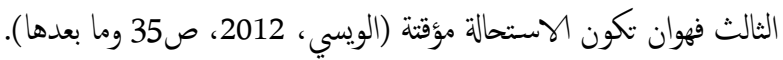

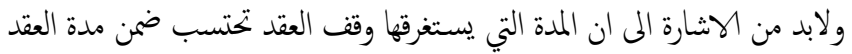

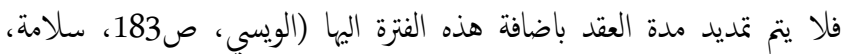

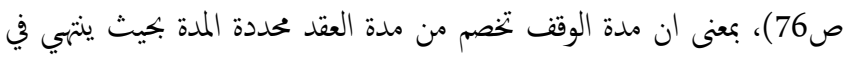
موعده الاصلي (زهران، ص686) مدة الوقن

\section{2}

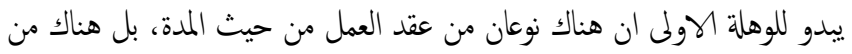

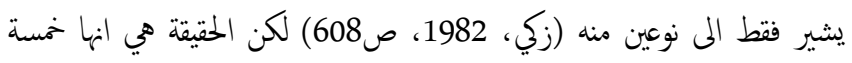
انواع، كما يأتي:

\subsection{1 اولاعقد عمل محددة المدة (لمدة معينة) :}

لقد عرف بانه (العقد المضاف المى اجل فاسخ)(نفس المصدر، ص613)، فيعني

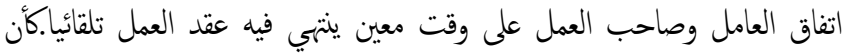

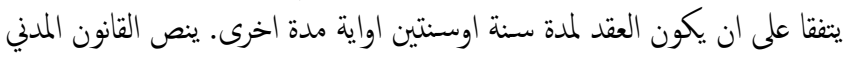

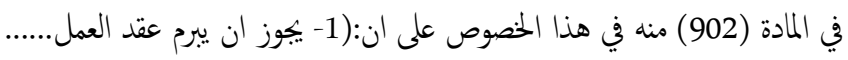

لمدة محدة....).

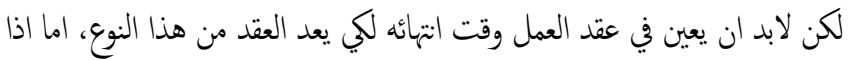

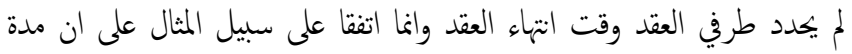

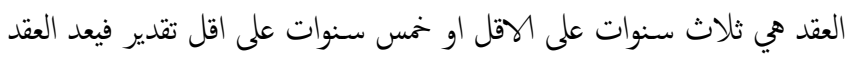

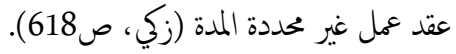

\section{3.2.2 - 3 انيا-عقد عمل غير محددة المدة :}

يعني اتفاق العامل وصاحب العمل على استمرارعقد العمل لمدة غيرحددة، اوان

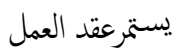
الى اجل غير مسمى. كأن يتفق رب العمل مع العامل على ان يعمل الحمل الحير في

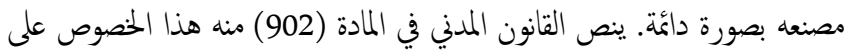
ان:(1-يجوزان يبرم عقد العمل...اولمدة....اوغير محددة). 
ببقي على وصف عقد العمل الذي تم تجديده فيبقى عقدا محددة المدة (كيره، ص

2- العمل القابل للتجديد بطبيعته :

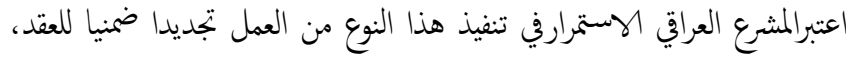

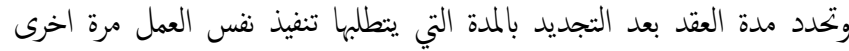

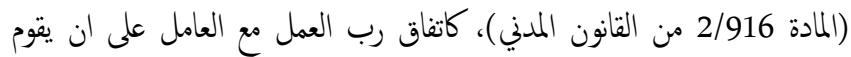

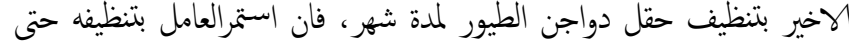

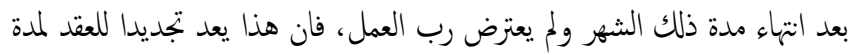

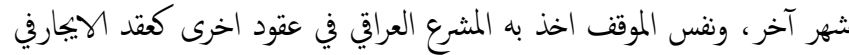

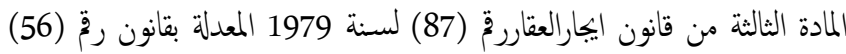
لسنة المن 2000.

ويلاحظ ان موقف المشرعين المصري والسوري مطابقان لموقف المثرع العراقي

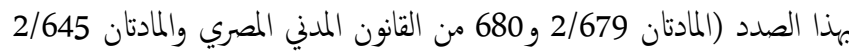

و646 من القانون المدني السوري).

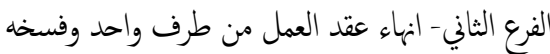

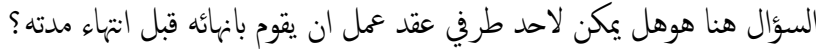

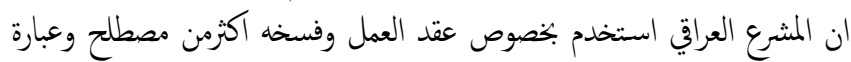

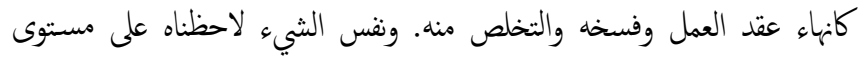

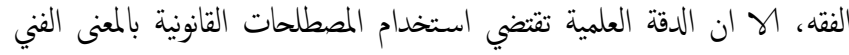

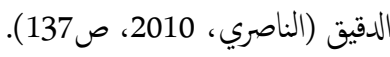

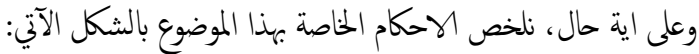

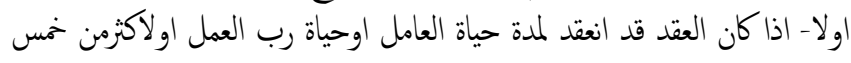

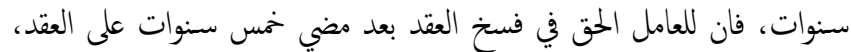

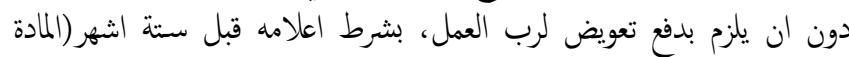
2/902 من القانون المدني العراقي).

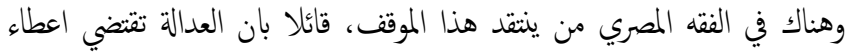

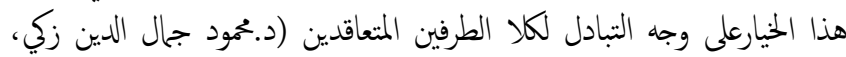

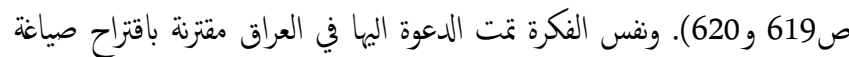

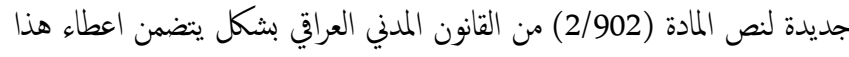

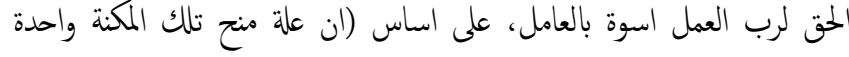

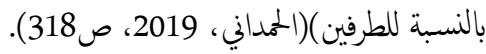

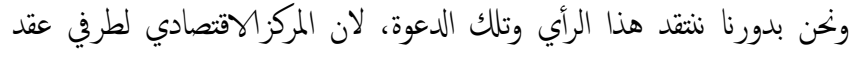

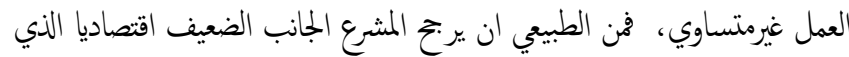

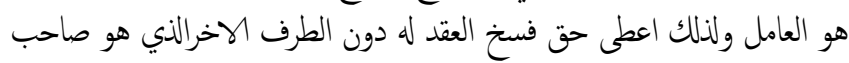
العمل. ثانيا- اذا كان عقد العمل غيرحددة المدة، فان المشرع العراقي تناوله في الفقرة

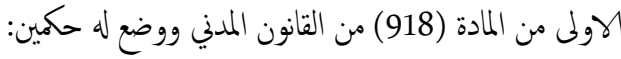

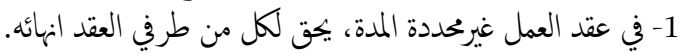

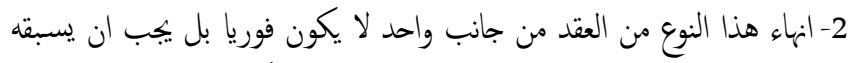

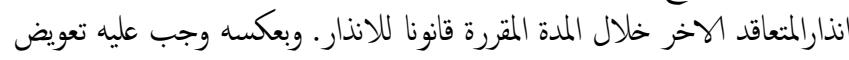
المتعاقد الاخر. وقد اورد المثرع في النص المذكورعقد عمل غير محددة المدة وهذا يعني ان

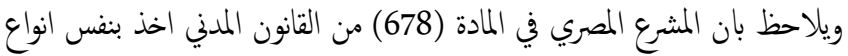

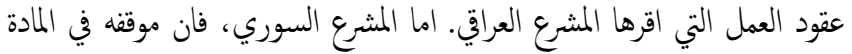

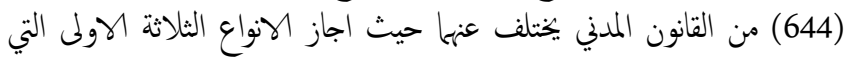

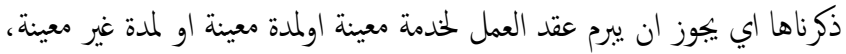

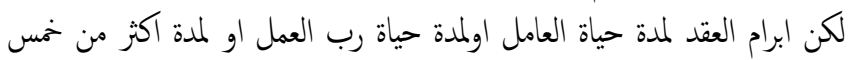

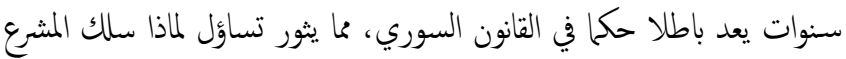

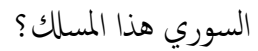

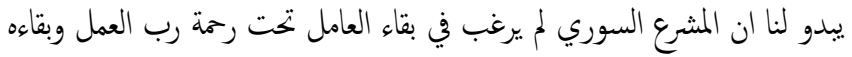

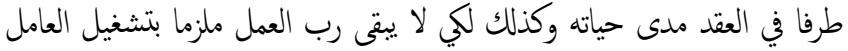
لايه طيلة حياته، لذلك تبنى هذا الموقف.

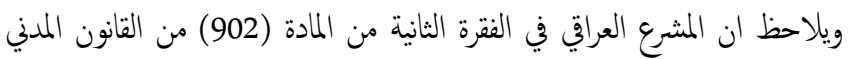

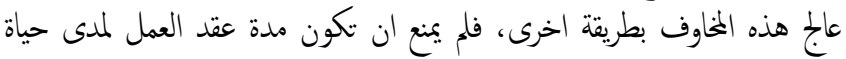

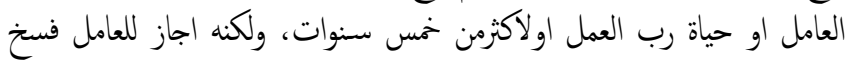

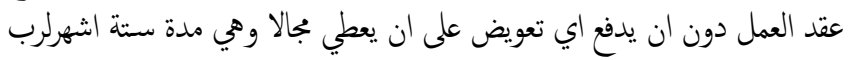
العمل. وفي رأينا ان موقف المشرع العراقي هو الافضل لانه اعطى دورلارادة المتعاقدين

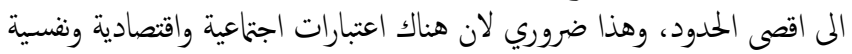

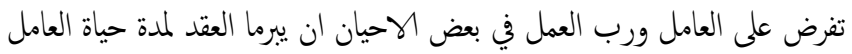

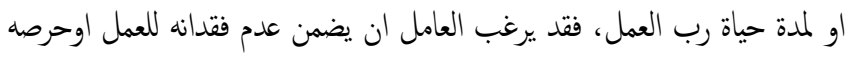

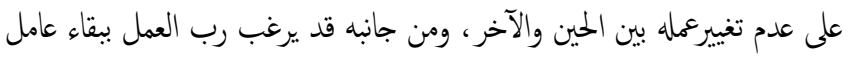

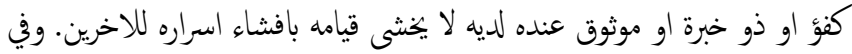

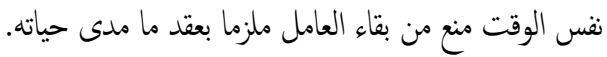

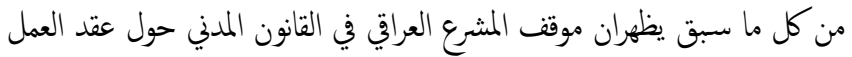

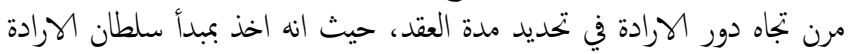

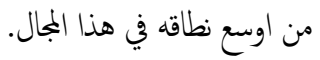

\section{3}

ان المثرع وضع احكام متعلقة بالمدة في عقد العمل لابد من التطرق اليها ودراستها

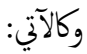
الفرع الاول - استمرار المتعاقدين رغز انتهاء مدة العقد

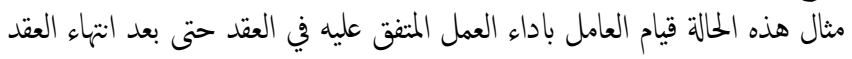

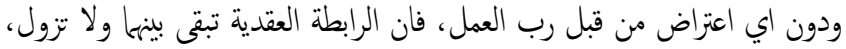

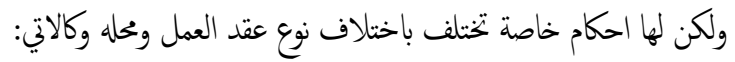

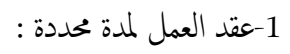

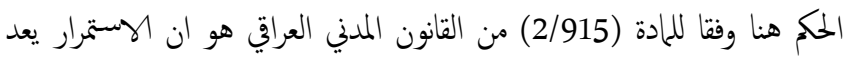

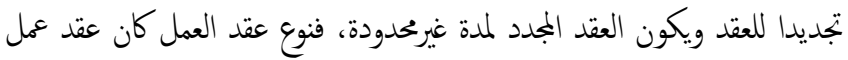

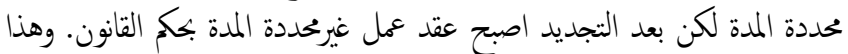

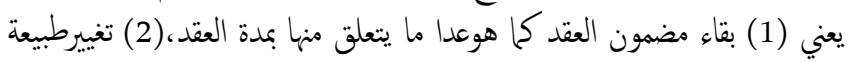

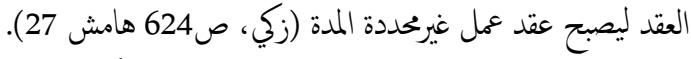

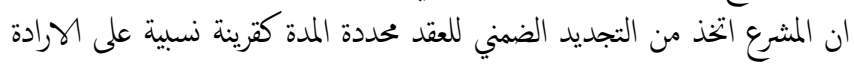

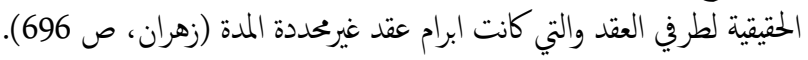
هنا يظهر الاختلاف بين التجديد الصريح والتجديد الضمني، فالاول كقاعدة عامة الماند 


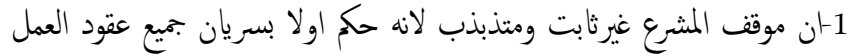

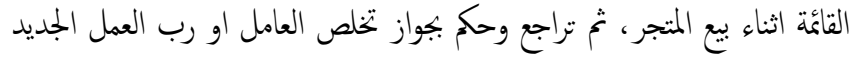

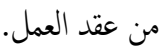
2-هذا الموقف يضربالعمال اذا قام رب العمل الجديد بالتخلص من عقود العمل

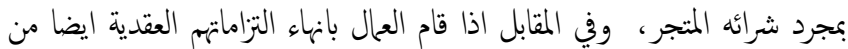
شأن ذلك ان يصيب رب العمل الجديد بالاضرار. سادسا-بالنسبة لتأثيروفاة احد طرفي عقد العمل على حياة العقد، تصدت له المادة الماد المان

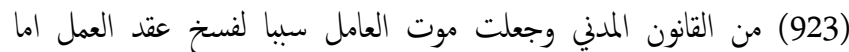

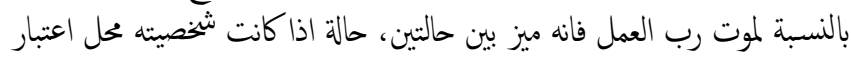

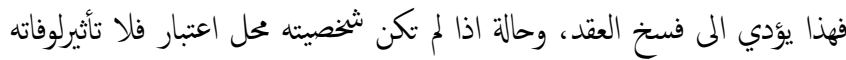

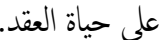
ونرى بان الحكمة من وراء هذا الموقف هي ان شيخصية رب العمل لا يكون محل

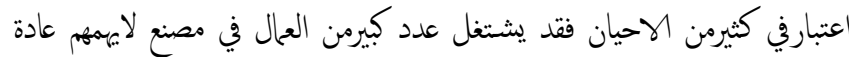

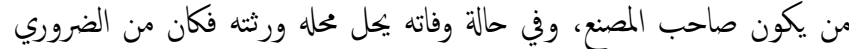

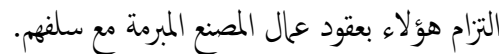

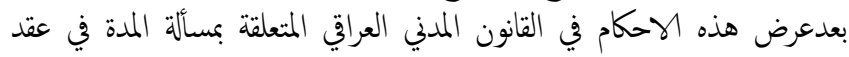
العمل، نبدي فيما يلي ملاحظتين:

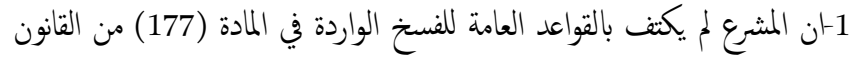

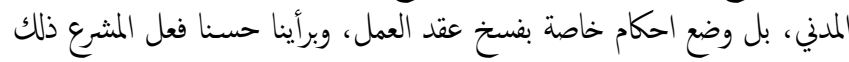

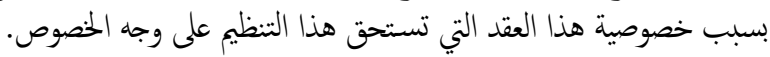

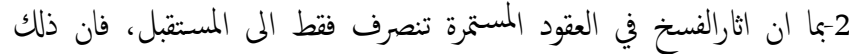
ينطبق على جميع حالات فنخ عقد العمل، لانه من العقود المستمرة.

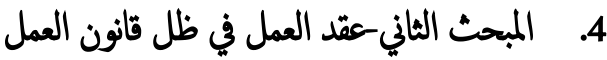

خصصنا هذا المبحث لدراسة عقد العمل في ظل قانون العمل، فني العراق قبل

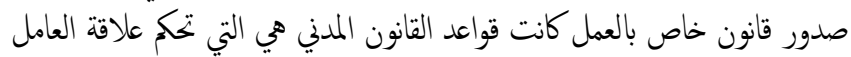

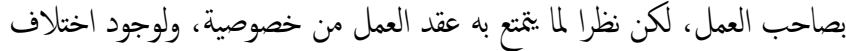

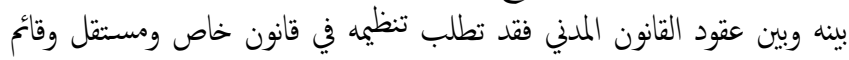

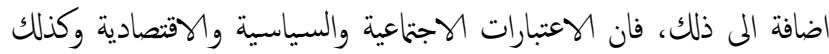

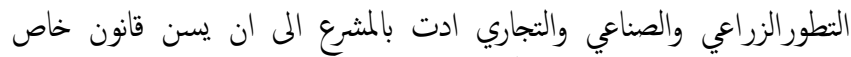

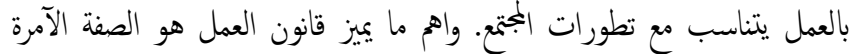

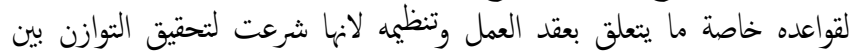

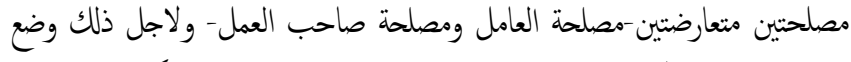

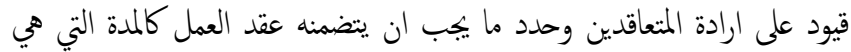
موضوع بحثنا. ولبيان دور واهمية عقد العمل في علاقات العمل وكيفية قيام المثرع بالتدخل

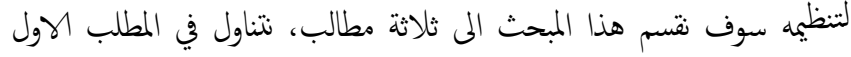

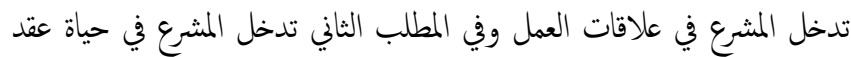

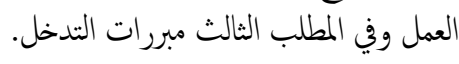

\section{1}

الحكمين السابقين يطبقان فقط على هذا النوع من عقد العمل.

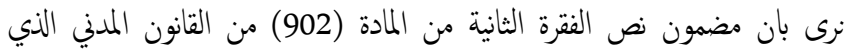
درسناه في الفترة (اولا) اعلاه يشمل ايضا الحالة الواردة في الفقرة الاولى من المادة المادة الماند

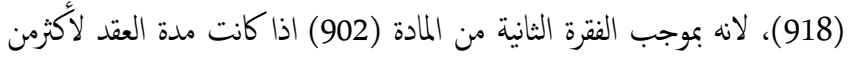

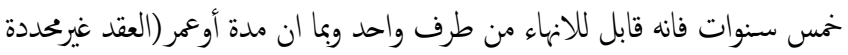

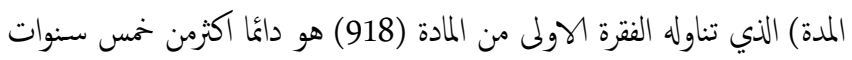

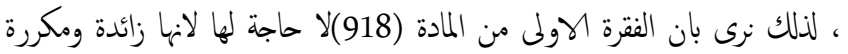

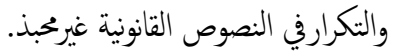

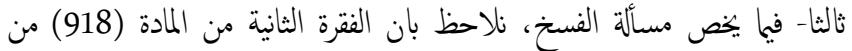

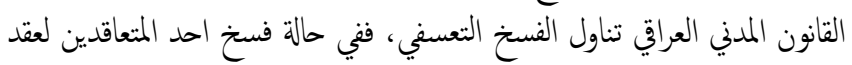

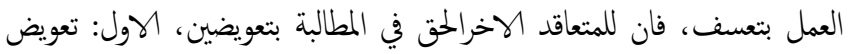

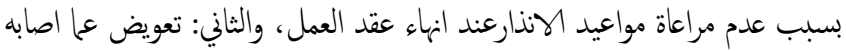
من ضرر. ان الحكم السابق مههم لانه في الفقرة الاولى من المادة نص المشرع على حالة انهاء

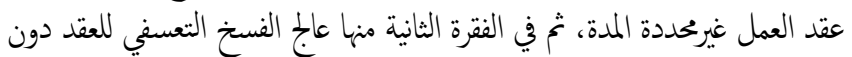

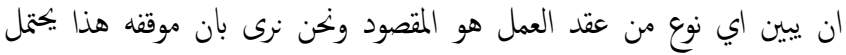

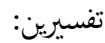
اولملما-ان هذه الفقرة تشمل جميع عقود العمل ايا كان نوعه طالما العقد جاء بشكل

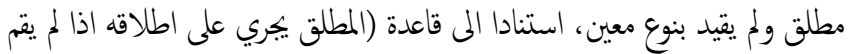

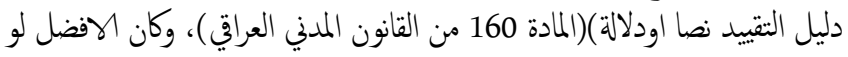
ان المشرع حدد نوع عقد العمل المشمول باحكام هذه المقام الفقرة.

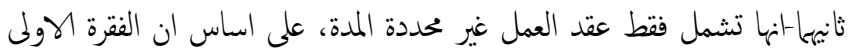

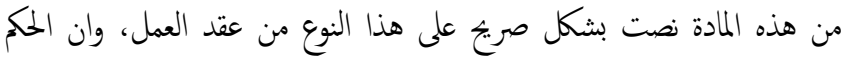

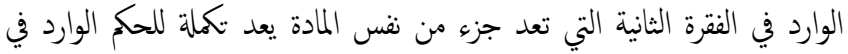
الفقرة الوولى منها. ومن مفهوم المخالفة للفقرة الثانية من المادة (918) المشاراليها، يمكن ان نستنتج بان

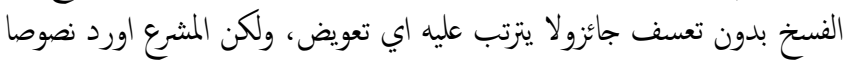
اخرى تؤكد ذلك بشكل صرئ، وهذا ما نتناوله في الفقرة التالية.

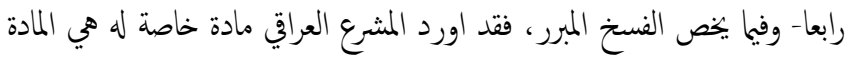

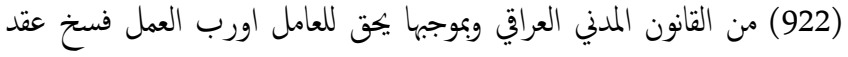

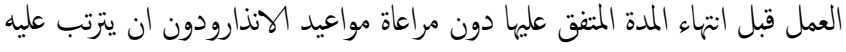
اي تعويض (الفقرة الثانية من المادة المذكورة).

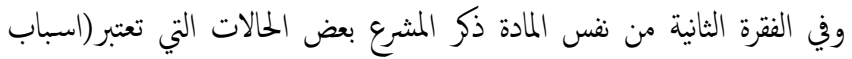

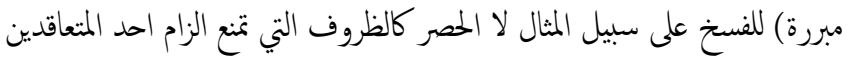

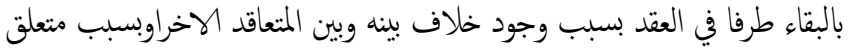
بقواعد حسن النية الواجبة في الاععال.

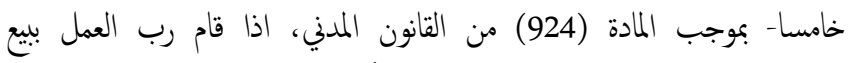

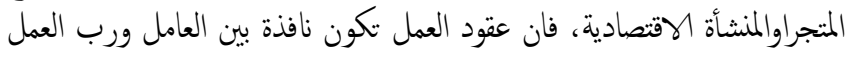

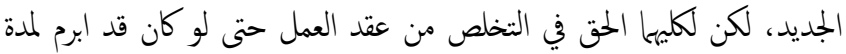

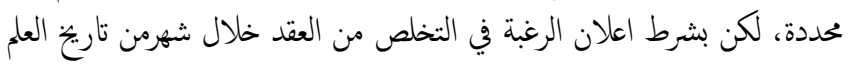

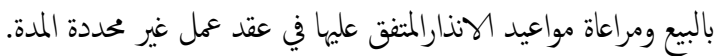
ويككن لنا ان ننتقد نص المادة (924) من القانون المدني من زاويتين: 
ان المشرع بشكل عام لا يتدخل في حياة الافراد، هناك مجالات عديدة ترك

\section{2}

هنا تدخل المشرع يصل الى ذروته لان حياة العقد محكوم بمبدأ (العقد شريعة

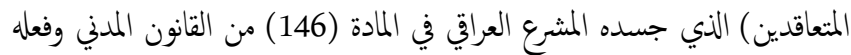

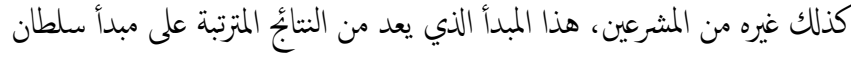

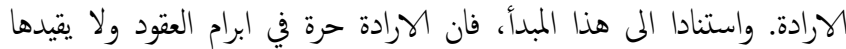

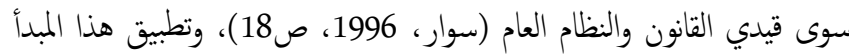

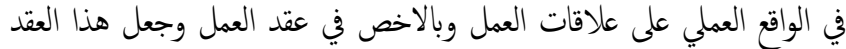

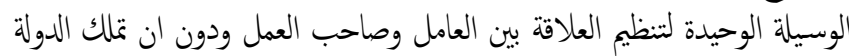

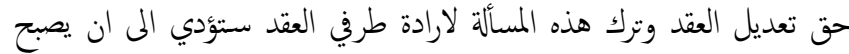

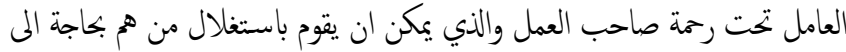

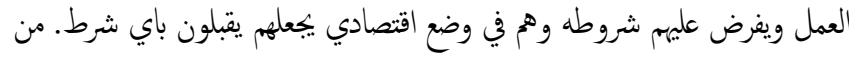
هنا دعت الضرورة الى الحد من مبدأ سلطان الارادة (العقد شريعة المتعاقدين)

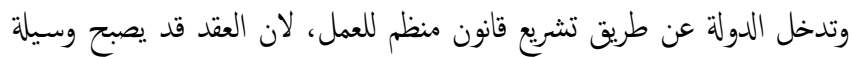

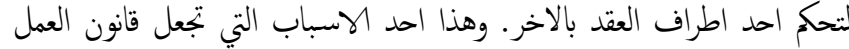

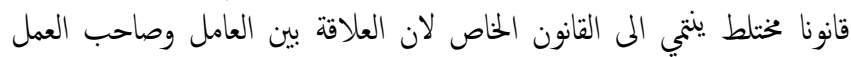

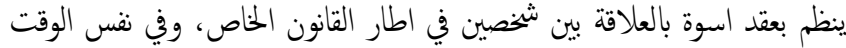
يتضمن قواعد قانونية تنتي المى القانون العام كالتحكيم والثنتيش وغيرها.

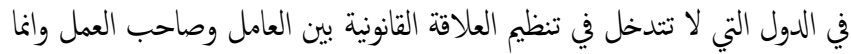

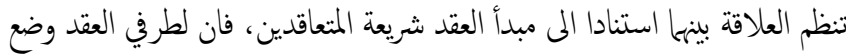

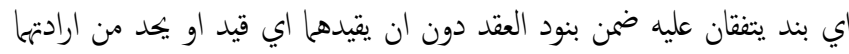

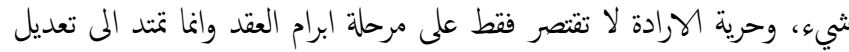

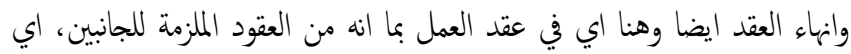

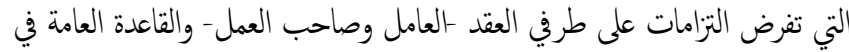

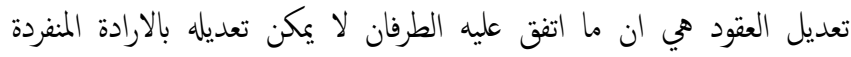

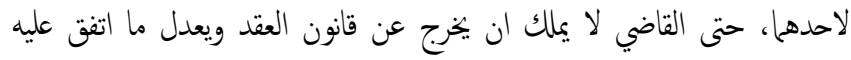

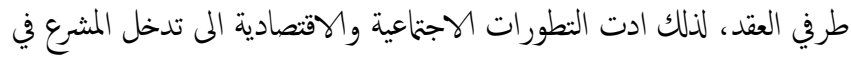

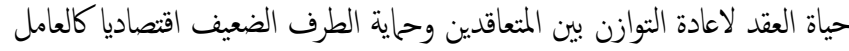

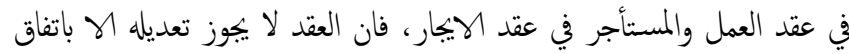

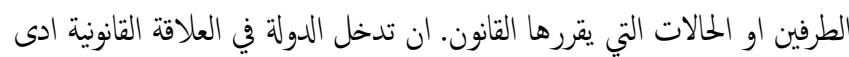

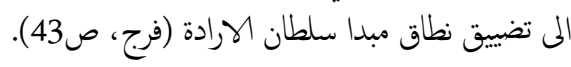

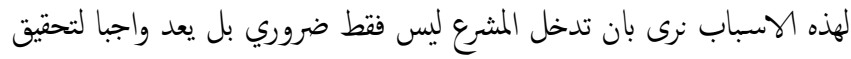
التوازن بين مصلحة صاحب العمل والعامل عن طريق تنظيم احكام عقد العمل.

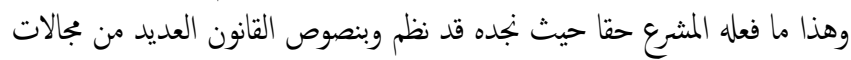

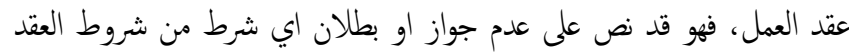

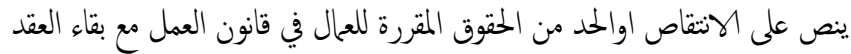

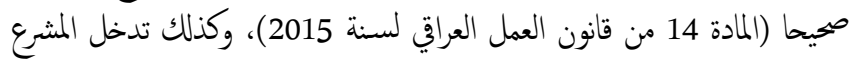

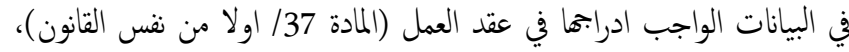

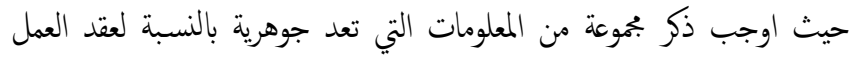

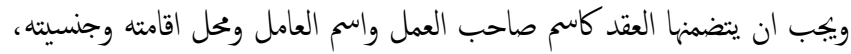

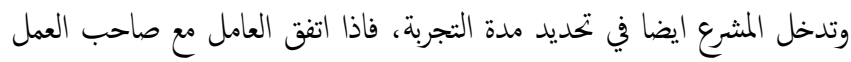

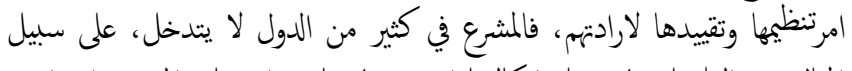

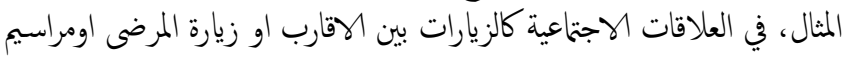

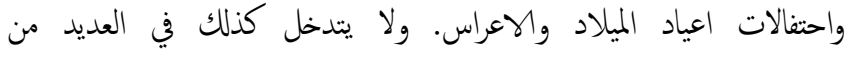
الامورالاقتصادية كالقيام بمشروع اقتصادي معين اواختيار وسيلة الدعاية لمنتج معين اوالمساهمة في شركة معينة.

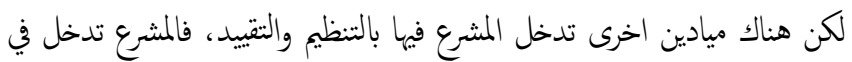

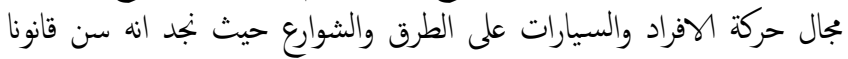
خاصا بالمرور وينطبق القول نفسه على النعليم الخاص.

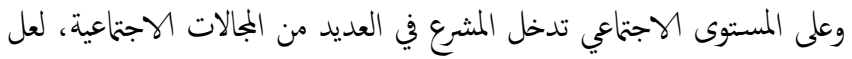

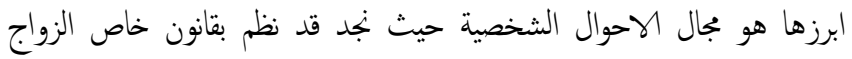

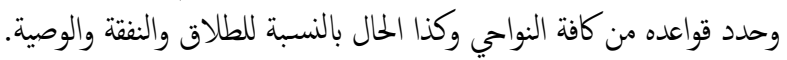

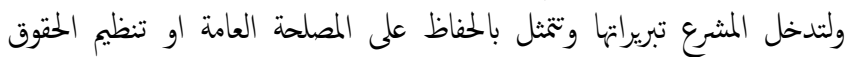

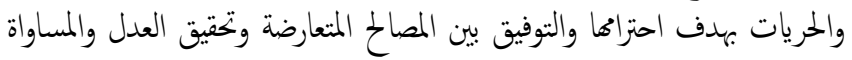

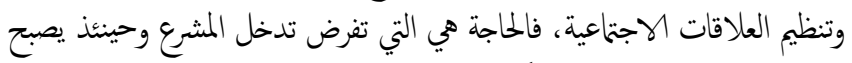

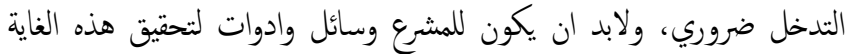

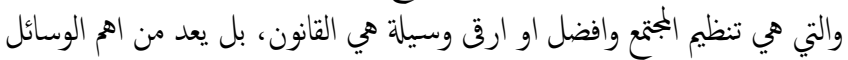

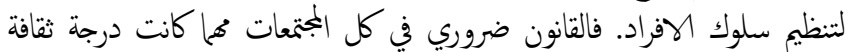

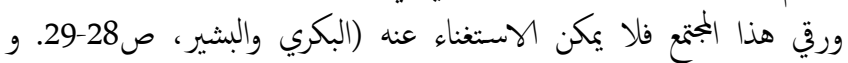

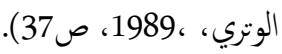

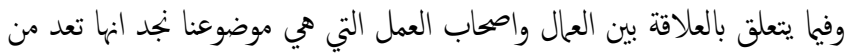

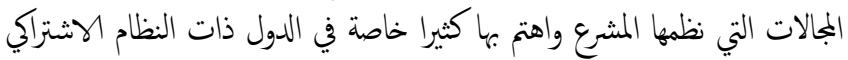

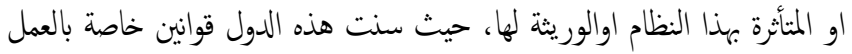

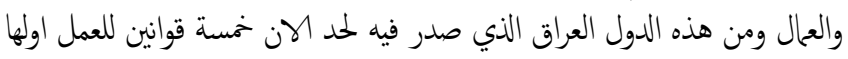

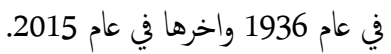

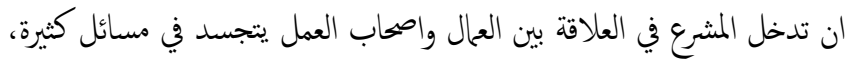

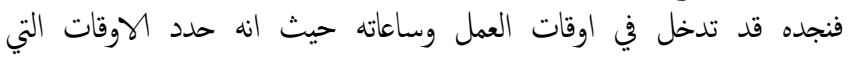

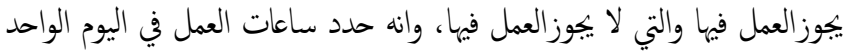

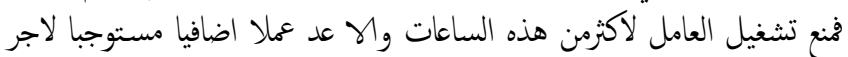

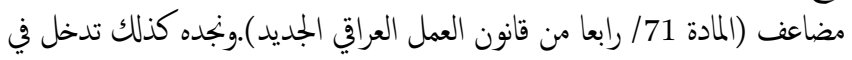

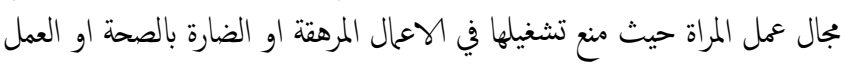

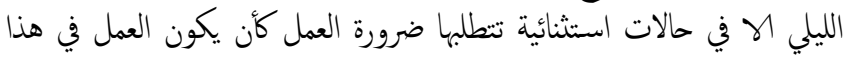

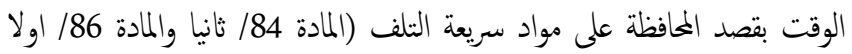
من نفس القانون). وتدخل في مجال تشغيل الاحداث وتم تحديد عمرالحدث لاغراض هذا القانون بانه

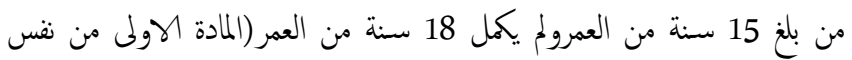

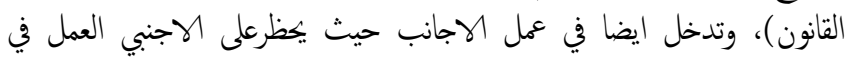

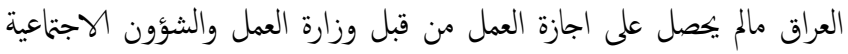

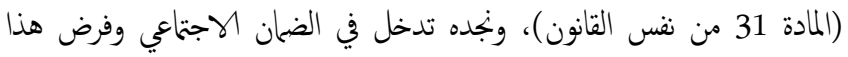

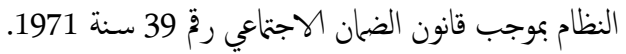

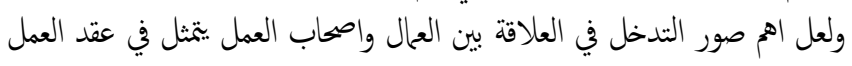

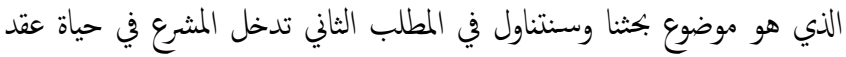


قانون العمل هي قواعد آمرة ينع طرفي العقد من الاتفاق على حكم خالف لما قرره

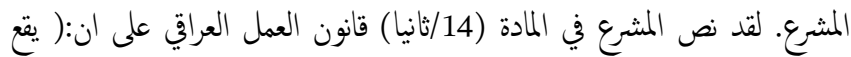

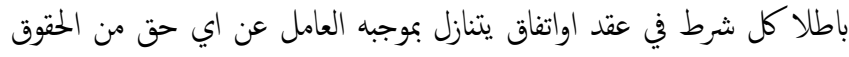

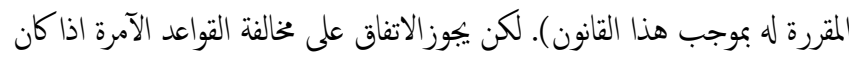

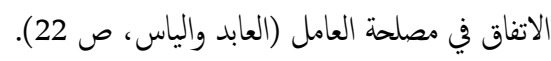

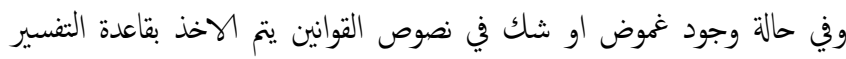

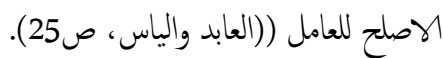

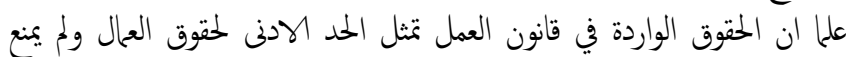

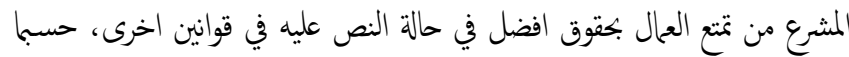

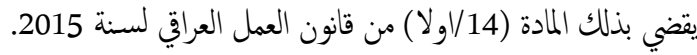

\subsection{2 الفرع الثاني - حاية الامن والسلم الاجتاعي}

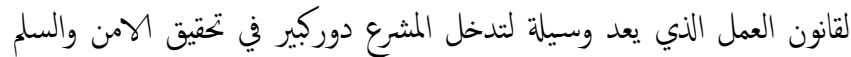

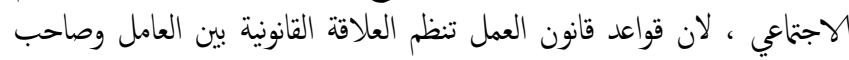

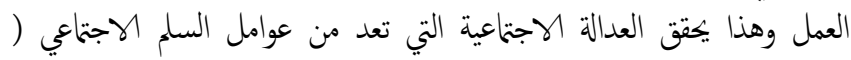

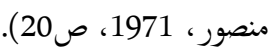
ان تدخل المشرع بتنظيم الرابطة القانونية بين العال واصحاب العمل بهدف تحتيق

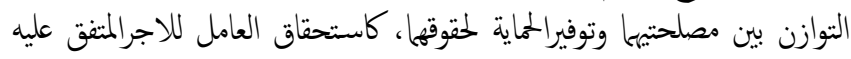

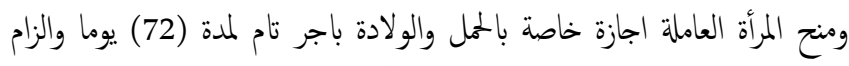

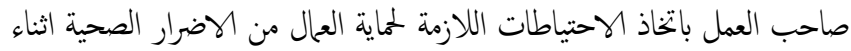

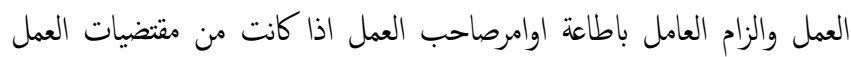

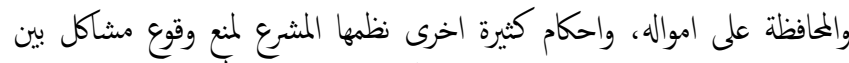

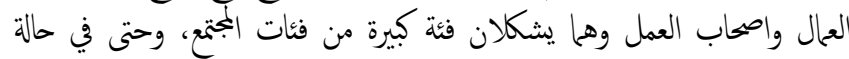

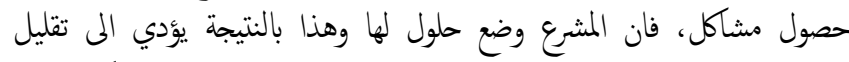

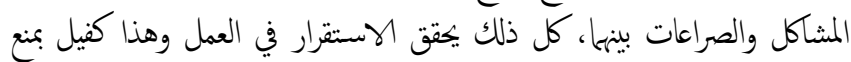
الاضطراب وتوفير الامن والسلم في الجمتع.

\subsection{3 الفرع الثالث - حاية الكتصاد الوطني}

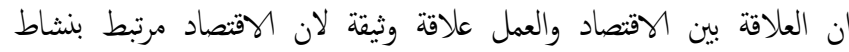

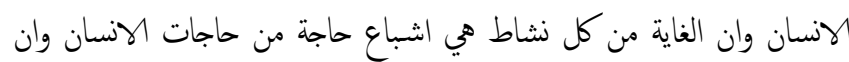

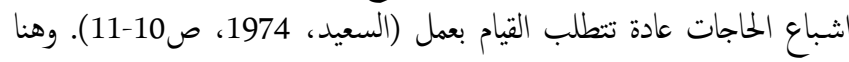
يرتبط الاقتصاد بالعمل والعال.

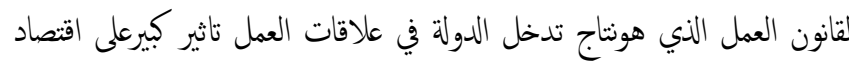

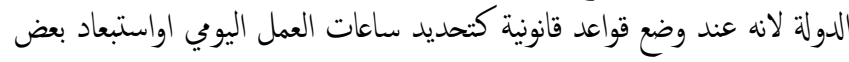

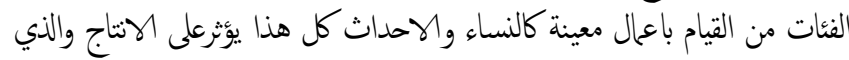

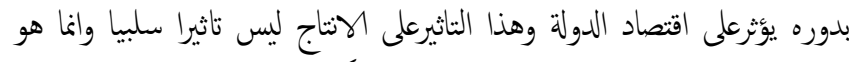

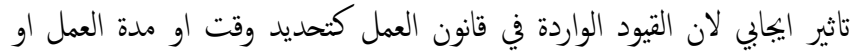

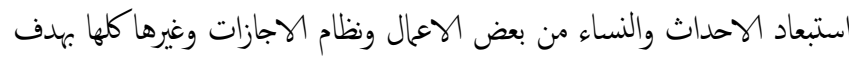

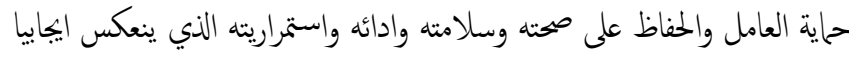

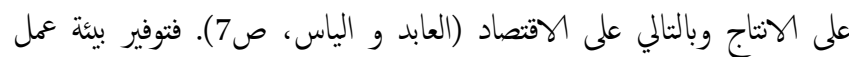

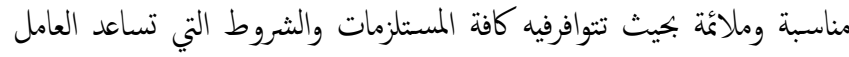
على القيام بواجباته ويكفزه على الانتكار يوثرتلى عملية الانتاج والتي بدوره
على ان الاخيريق له ان يضع العامل تحت التجربة لمدة معينة لاكتساب المهارة،

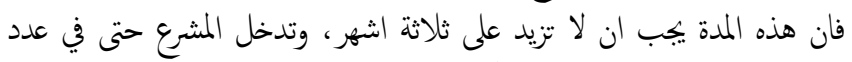

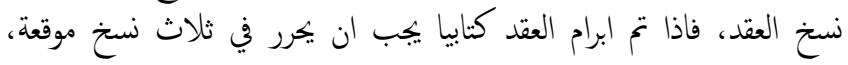

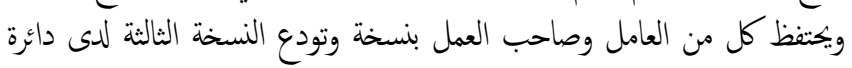
التشغيل والقروض (نف المادة). ولعل امز صور تدخل المشرع في حياة عقد العمل، تدخاه في مدة عقد العمل الني هو موضوع بكثنا هذا.

\section{3}

بعد ان بينا تدخل المشرع في علاقات العمل وفي حياة عقد العمل في المطلبين

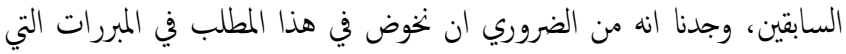

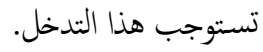

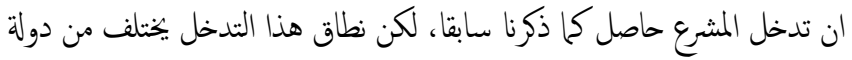

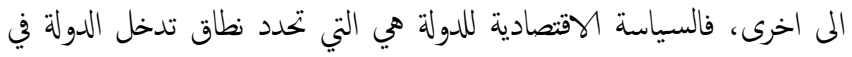

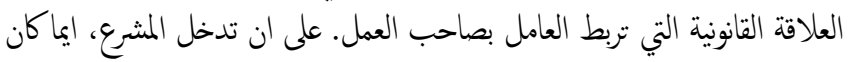

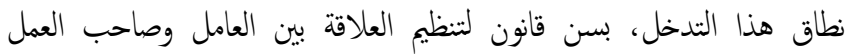

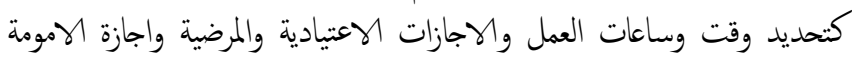

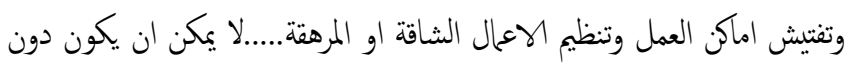

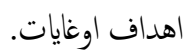

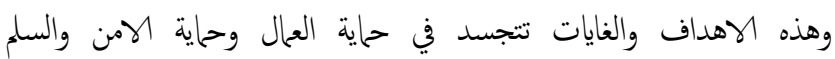

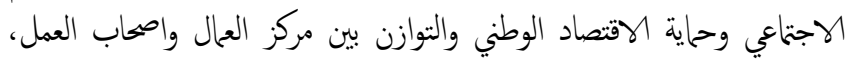
وسوف نتناول كل من هذه الغايات في اربعة فروع مستقالة كلاتئ:

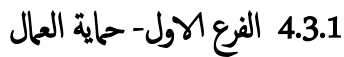

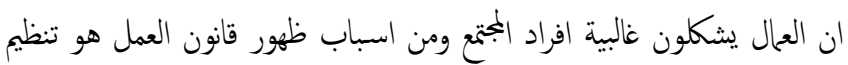

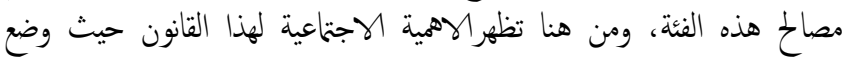

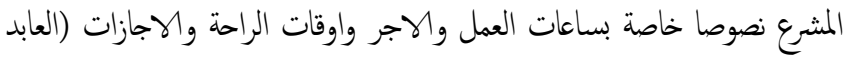

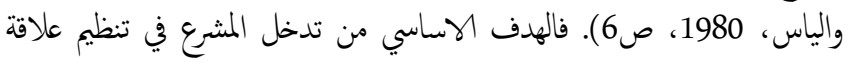

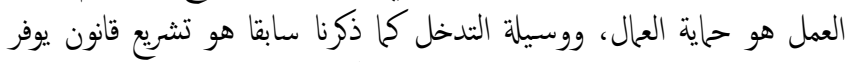

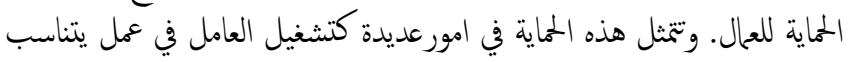

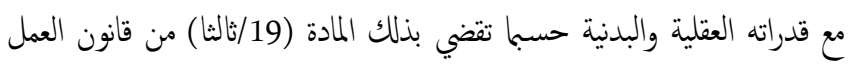

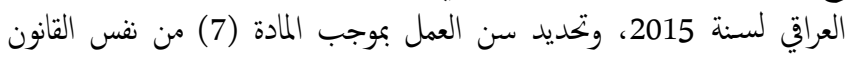

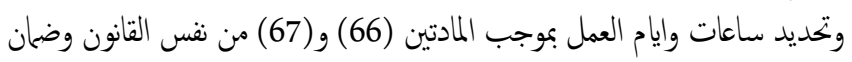

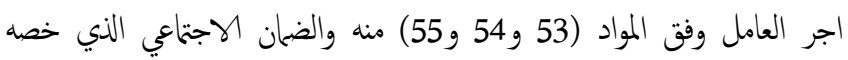

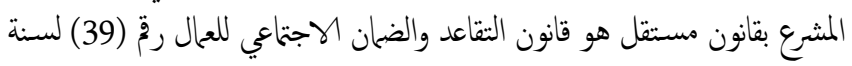
1971

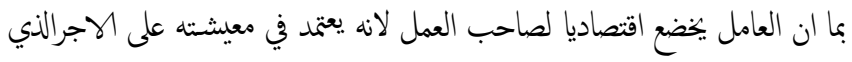

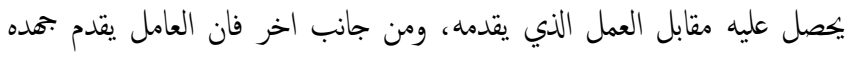

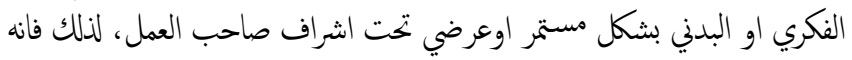

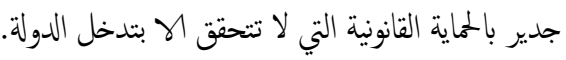

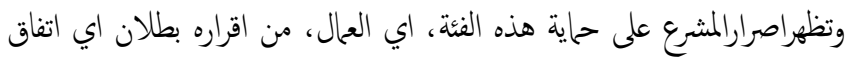

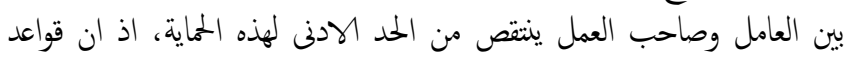


ان للمدة دور بارزفي عقد العمل في ظل احكام قانون العمل مثلما كان له هذا

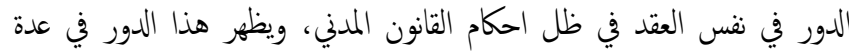

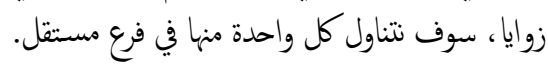

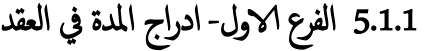

اوجب المشرع العراقي في المادة (37/اولا) من قانون العمل العراقي لسنة 2015

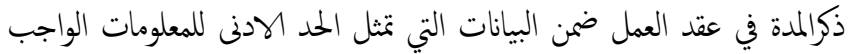

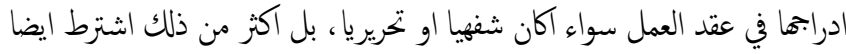
تحديد تاريخ بدء العمل اضافة الى طبيعته ونوعه.

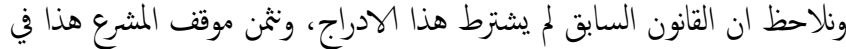

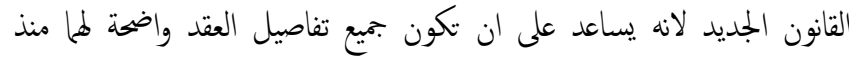

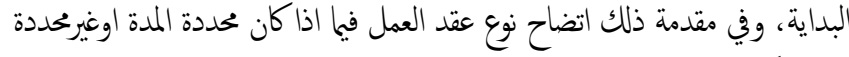
المدة، وكذلك تاريخ انتهاء العقد.

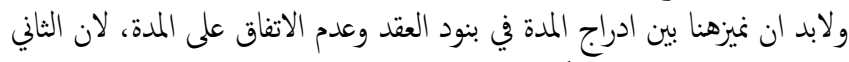

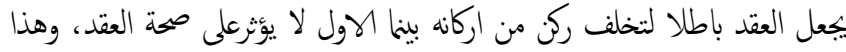

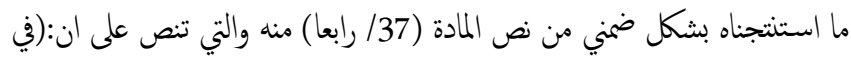

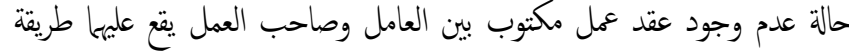

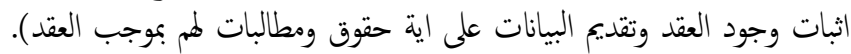

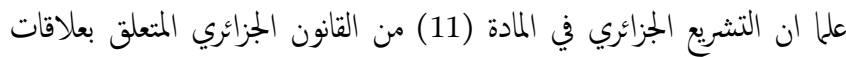

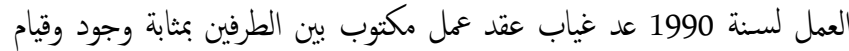
علاقة عمل غير محددة المدة، وموقف المشرع السوري في المادة (48) من قانون العمل لسنة 2010 مطابق

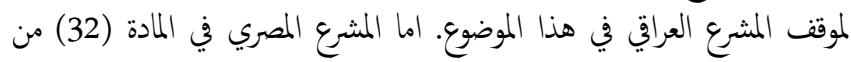

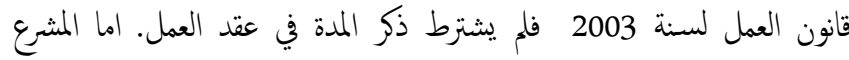

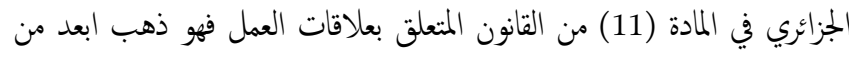

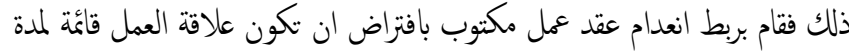

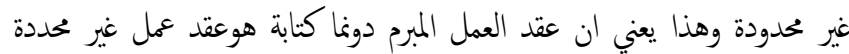

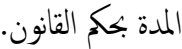

\subsection{2 الفزع الثاني- مدة التجربة}

بموجب المادتين (37/ ثالثا) و(43/ ثانيا/ ز) من قانون العمل العراقي الجديد

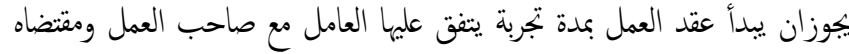

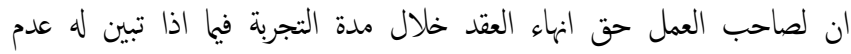

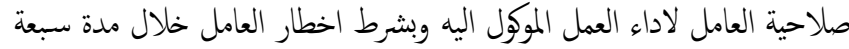

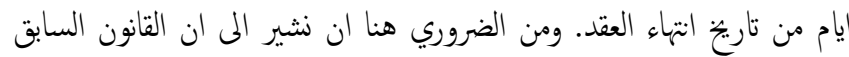

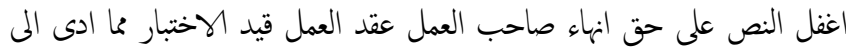

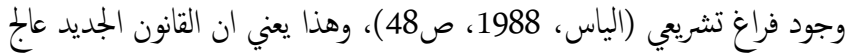

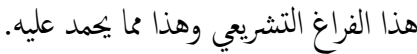
لكن ليس جميع العال يخضعون للتجربة اوالاختباربل وضع المشرع العراهيه العراقي في المادة

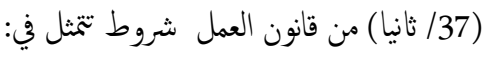

1-عدم امتلاك العامل شهادة هنية تثبت كفاوته في العمل محل العقد.

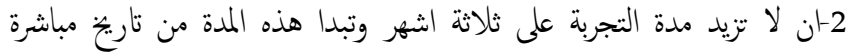

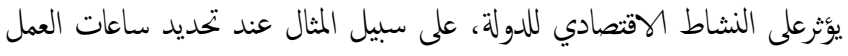

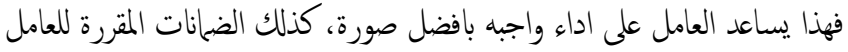
مثل الاجر والخدمات الصحية والاجازات واوقات المات الراحة.

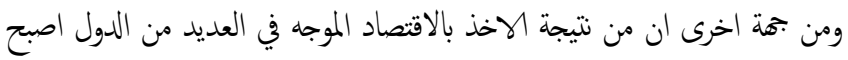

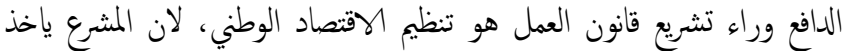

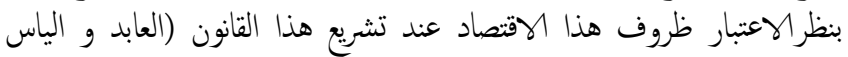

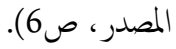

\subsection{4 الفع الرابع - التوازن بين مركز العال واصحاب العمل}

طالما ليس هناك مساواة في الوضع الاقتصادي لاطراف العقد، فان هذا يعطي

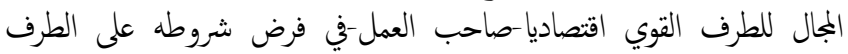
الاخرالذي هوالعامل، لهذا تدخل الدولة في العلاقة القانونية-استثناءامن مبدا فيدا

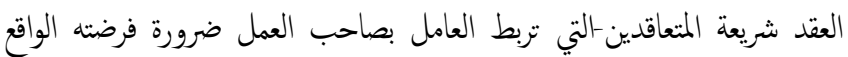

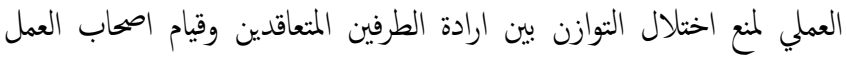

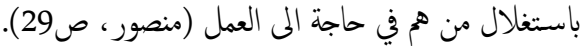

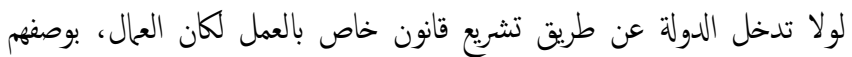

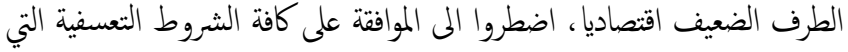

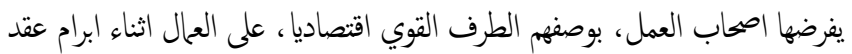

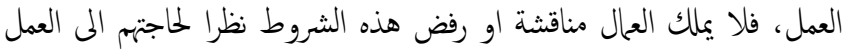

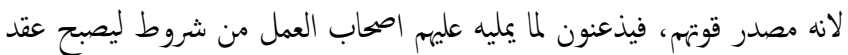

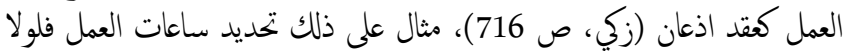

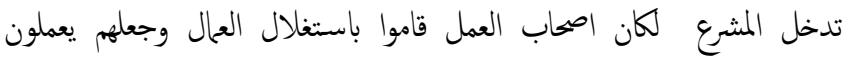

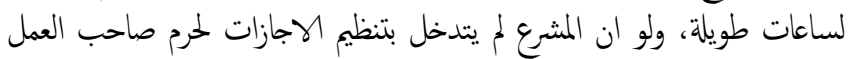

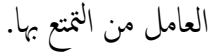

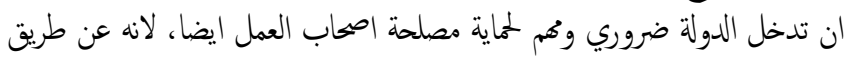

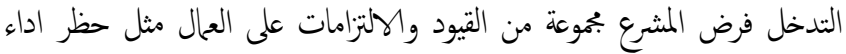

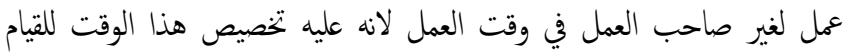

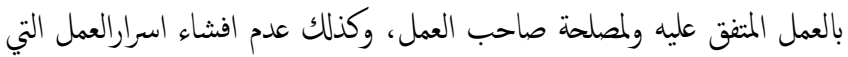

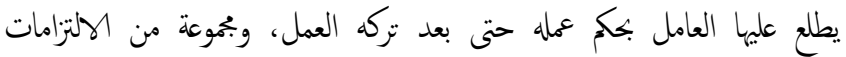

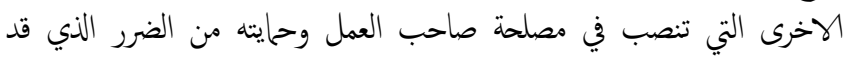
يصييه من العامل.

\section{5. المبحث الثالث- مدة عقد العمل في ظل قانون العمل}

ان المدة تعد من الامورالجوهرية التي يجب تحديدها ضمن بنود عقد العمل، وان

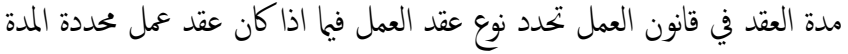

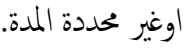
ومن اجل الاحطة بدورالمدة في عقد العمل في ظل قانون العمل بصورة وافية

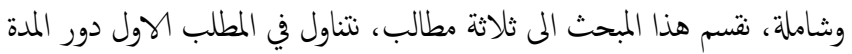

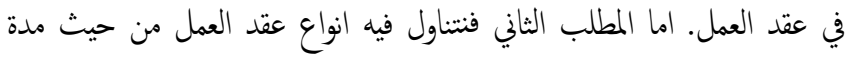

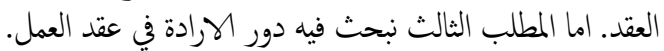

5.1 


\section{(5.2.1 الفزع الاول- عقد العمل محددة المدة}

لم يعرف قانون العمل عقد العمل محددة المدة بل اكتفى بذكرالحالات التي يعد فيها

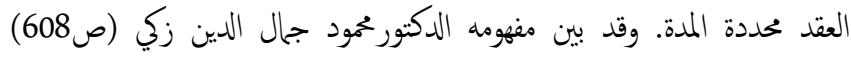

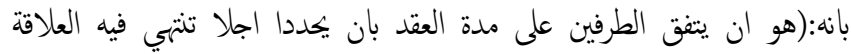

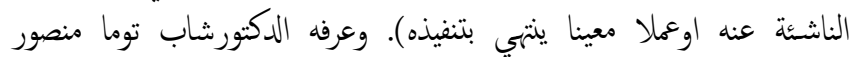

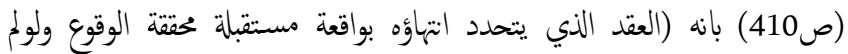

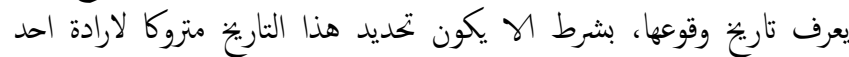

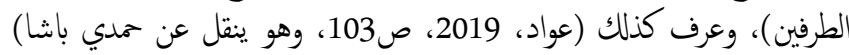
بانه (ذلك العقد الذي تتحدد نهايته بواقعة مستقبلية ومحققة لا يتوقف وجودادها

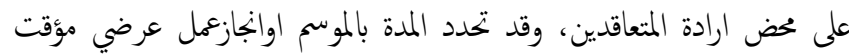

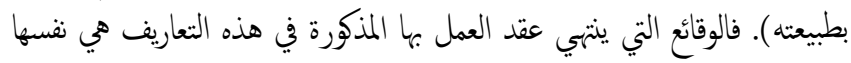

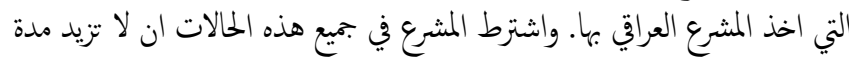

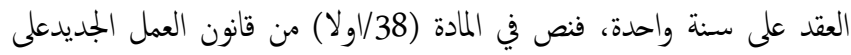

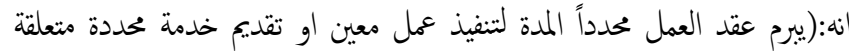

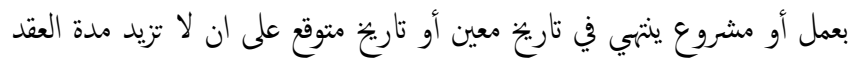

ذلك على سنة واحدة).

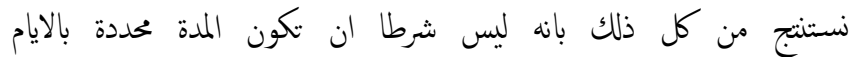

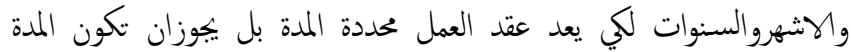

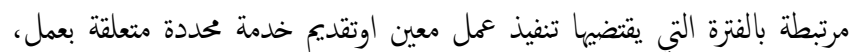

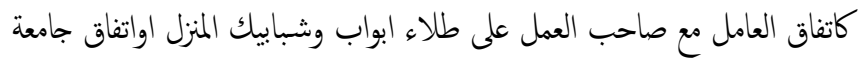
خاصة مع شخص ما لتنظيم حفلة تخرج الطلبة، اوبرمجة كتب الماكلمنبة.

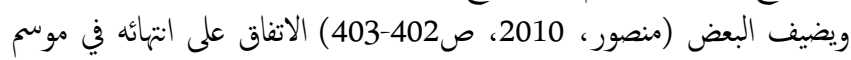

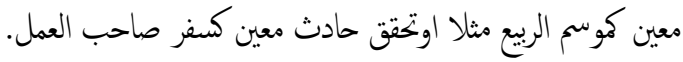

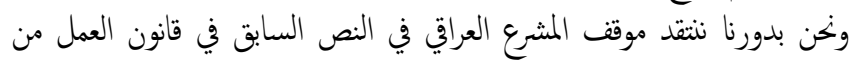

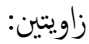

اولا- انه ربط عقد عمل محددة المدة بتنفيذ عمل معين اوتقديم خدمة معينة. وهذا

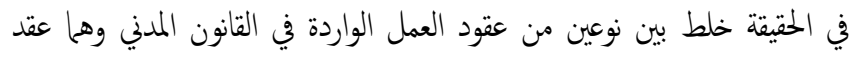

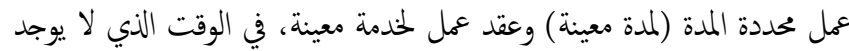

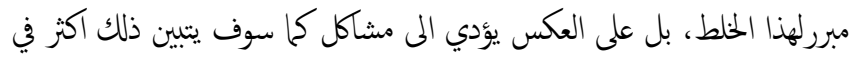

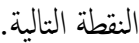

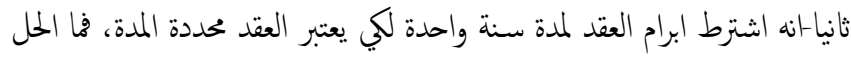

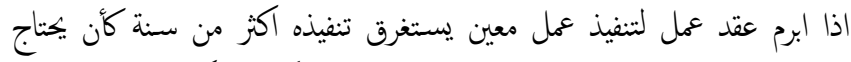

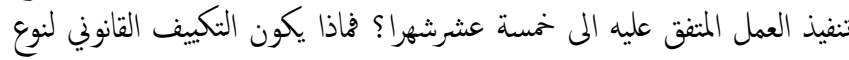

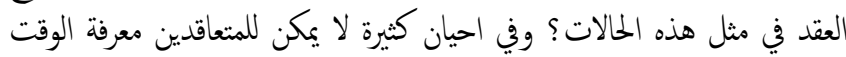

$$
\text { الذي يستغرقه تنفيذ العمل بدقة. }
$$

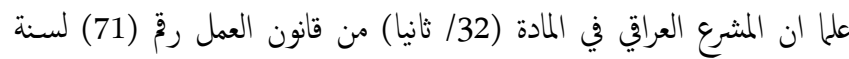

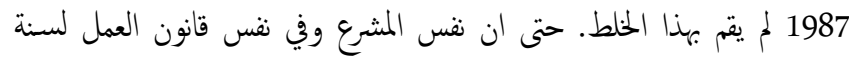

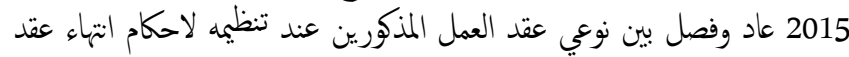

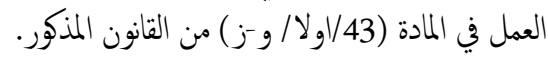

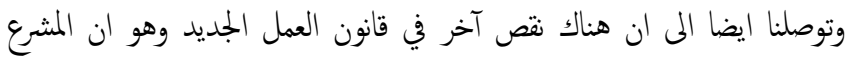

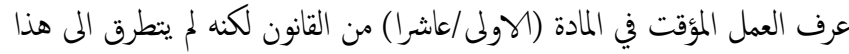

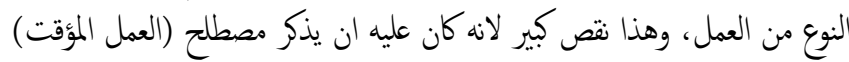

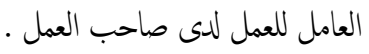

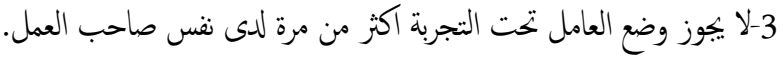

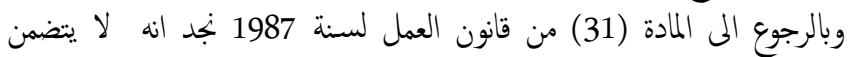

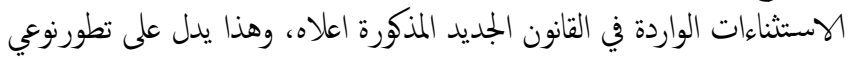

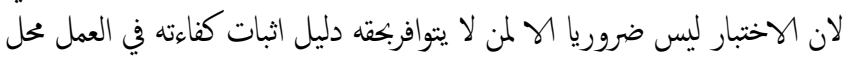

عقد العمل. - مقان. ويختلف موقف المثرع المصريفي المادة (33) من قانون العمل عن موقف العراقي

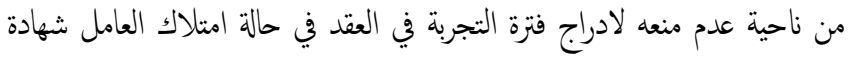

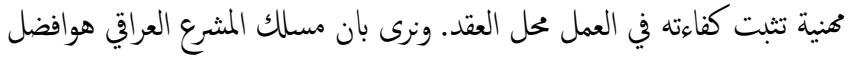

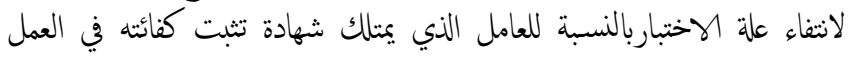

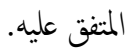

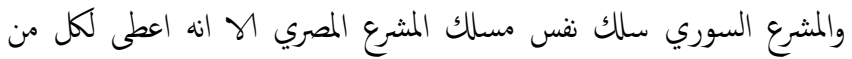

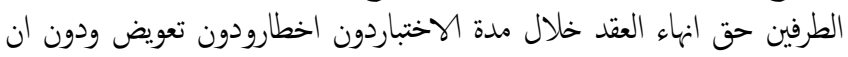

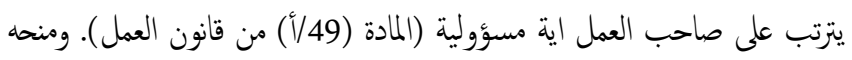

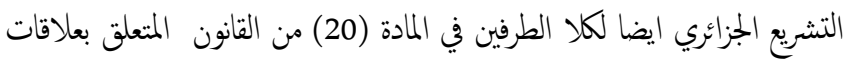

العمل.

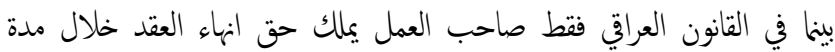

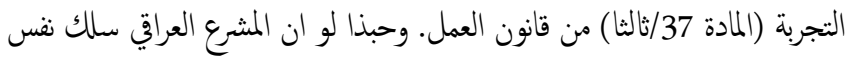

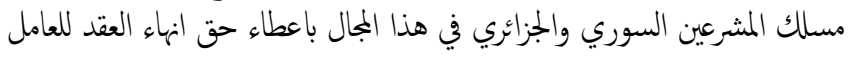

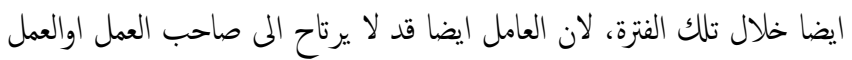

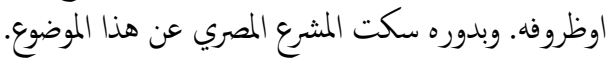

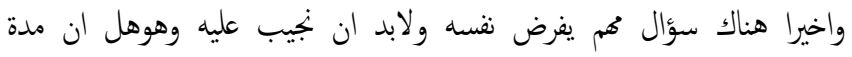

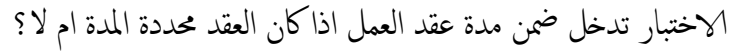

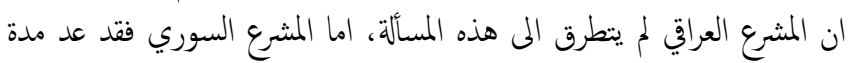

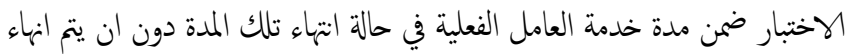

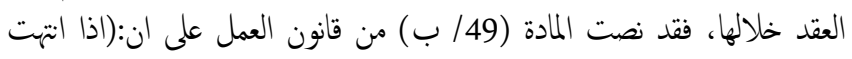

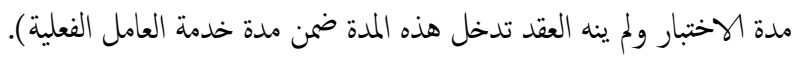

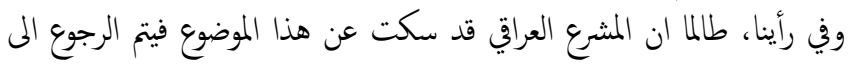

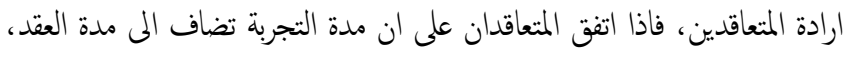

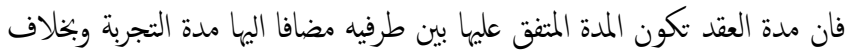
ذلك تدخل مدة التجربة ضمن مدة العقد.

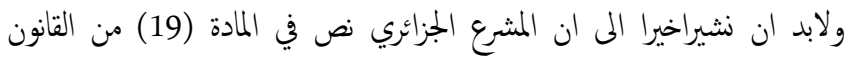

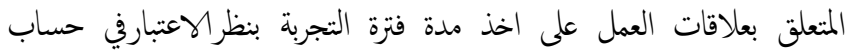

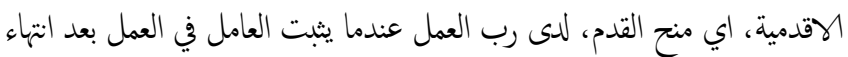

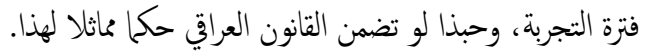

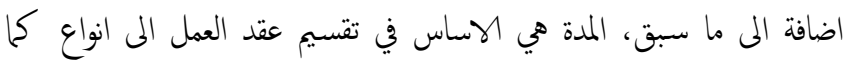
سنبحث في ذلك في المطلب اللاحق.

\section{2}

على عكس القانون المدني، قسم المثرع العراقي عقد العمل في قانون العمل الى الى

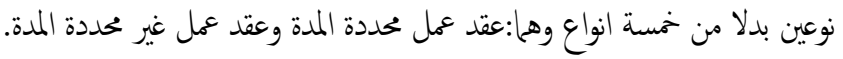


2-حتى ان القانون المدني في المادة (2/915) منه، تقضي بان التجديد حتى لو كان

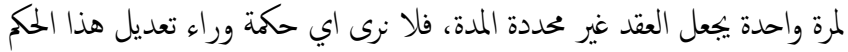

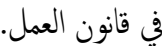
3-الحكم الحالي يضعنا امام مشكلة واقعية عندما يتفق المتعاقدان على التجديد لمرة

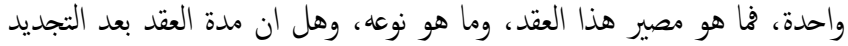

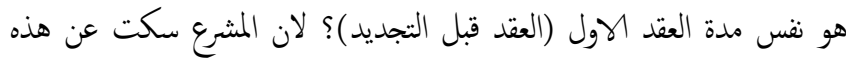
الامور وهي تحتاج الى تدخل من قبله لايجاد حل لهذه المسائل.

\section{3}

ان الارادة تعد الاساس في تكوين العقود المدنية، وان اطراف العقد بامكانهم

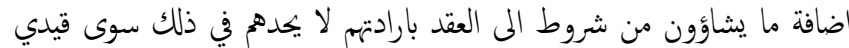

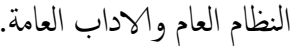
ومن هنا ندرس هذا الدورفي عقد العمل في ظل قانون العمل وكالاتي:

\subsection{1 الفع الاول- دورالارادة في ابرام عقد العمل}

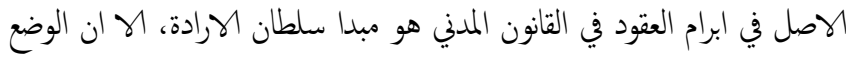

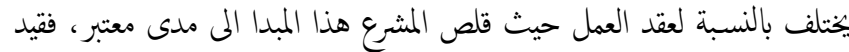

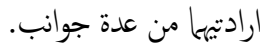
ومن المسائل التي وضع المشرع التيود على ارادة الطرفين مدة عقد العمل التي هي موضوع بحثنا، وكما يأتي:

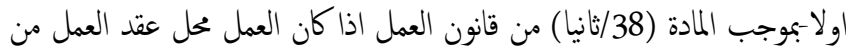

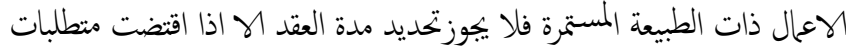

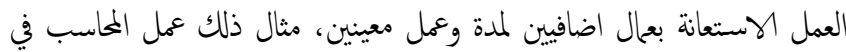

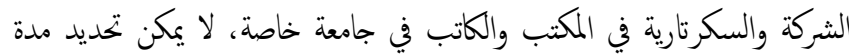

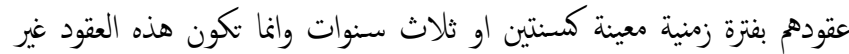

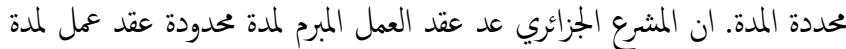

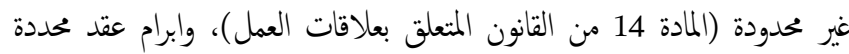
المدة في الاعحال ذات الطبيعة المستمرة يعد خلافا لاحكام القانون المذكور (المادة المادة

$$
\text { (12) من القانون). }
$$

ويظهرهنا جليا كيف ان المثرع قيد بشكل صارخ مبدا سلطان الارادة وتدخل

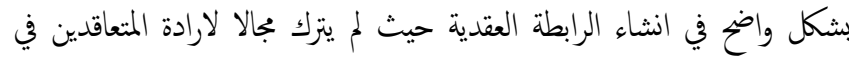

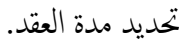

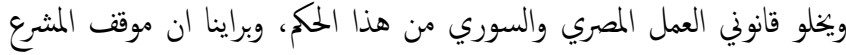

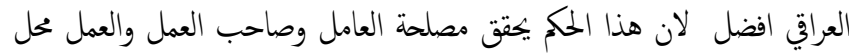

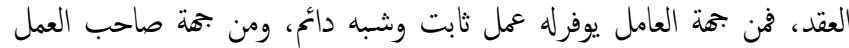

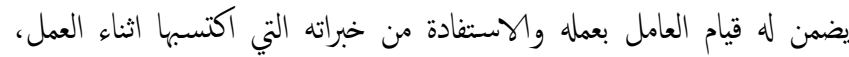

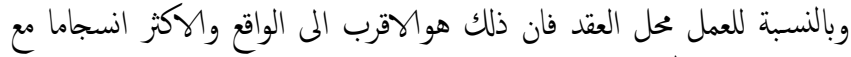

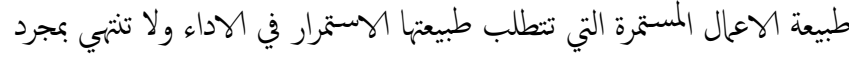

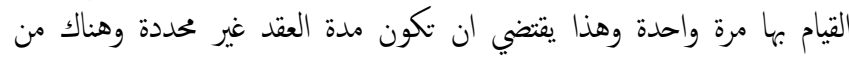

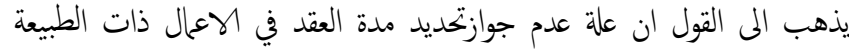

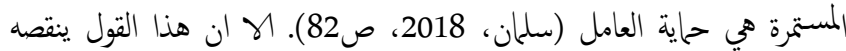
الدقة والصواب، فالعلة هي اوسع من ذلك بالتفصيل الذي بيناه اعلاه.

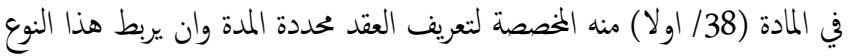

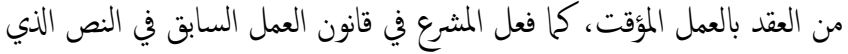

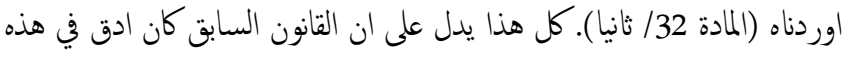

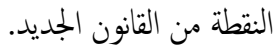
واخيرا من الضروري ان نشيرالى انه اذا كان العمل محل عقد العمل من الاعمال

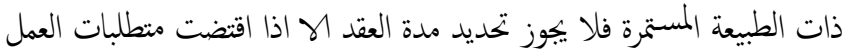

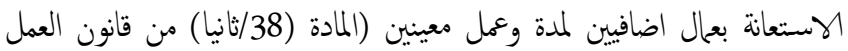

\subsection{2 الفرع الثاني- عقد عمل غير محددة المدة}

لم يعرف المشرع هذا النوع من عقد العمل، وبالاستفادة من مفهوم المخالفة لمفهوم

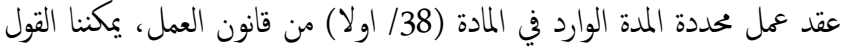

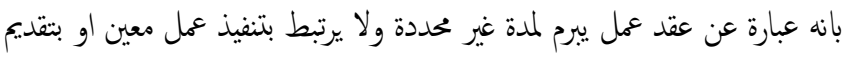
خدمة محددة ولا ينتهي في تاريخ معين.

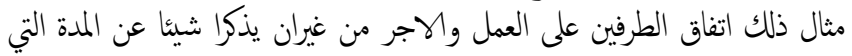

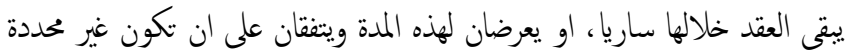

$$
\text { (اليعقوب، ص27). }
$$

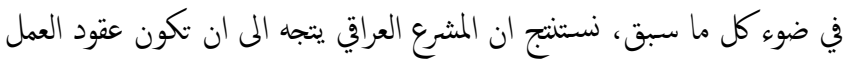

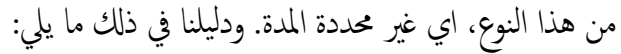

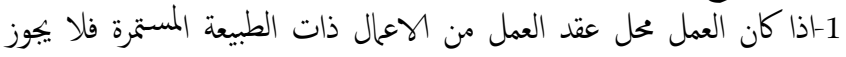
تحديد مدة العقد، اي يجب ان يكون العقد غير محددة المدة.

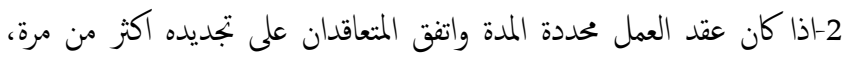

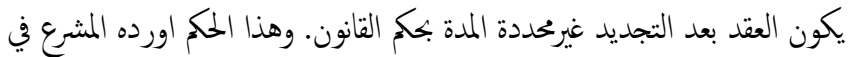

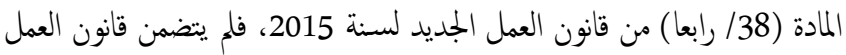
السابق حكما مماثلا. وما دام هناك موقف جديد للمشرع، لابد لنا ان نشيرالى علة هذا الحكي ومقارنته

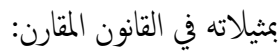

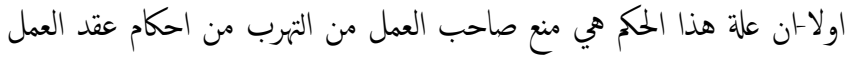

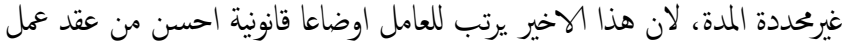

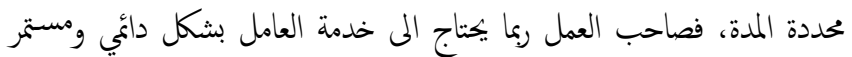

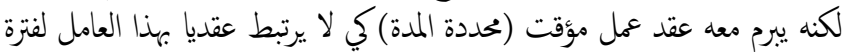

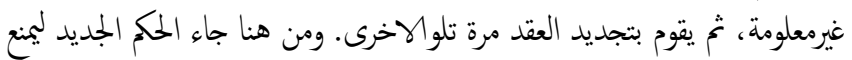

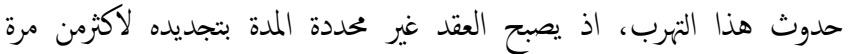

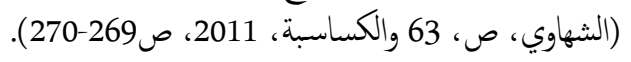

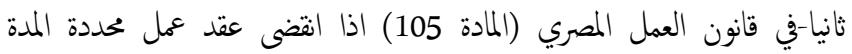

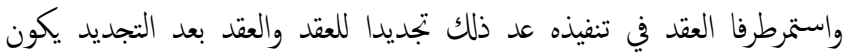

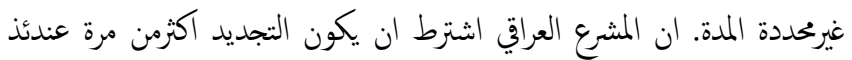

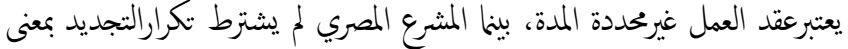

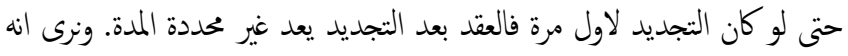

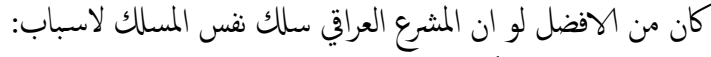

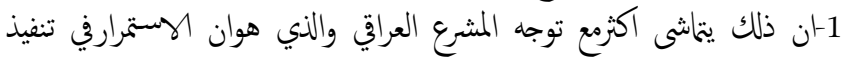
العقد يؤدي المى تجديده، كما اسلفنا. 
العقد باقية، كاتفاق العامل مع صاحب العمل على انهاء العقد مبكرا اوانهائه بارادة

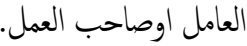

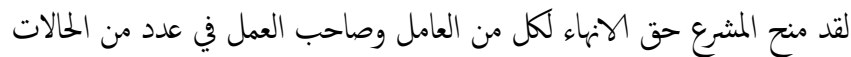

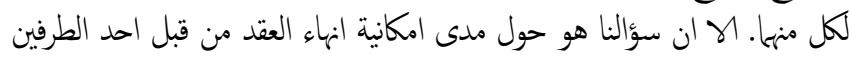

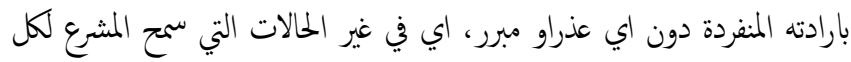

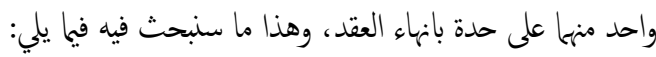

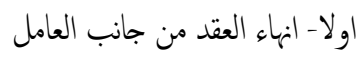

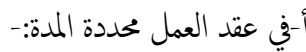

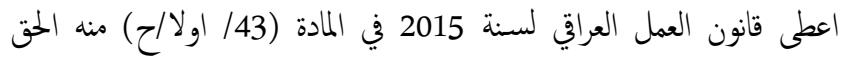

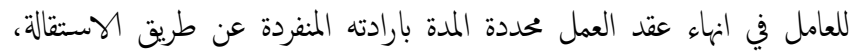

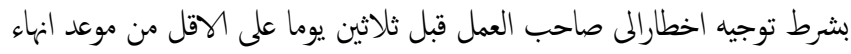

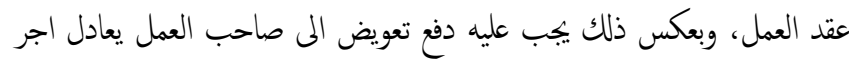
مدة الانذاراو ما تبقى منها.

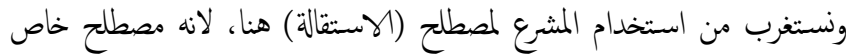

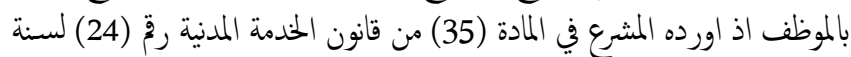

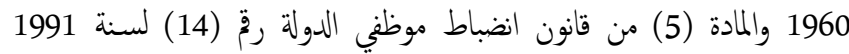

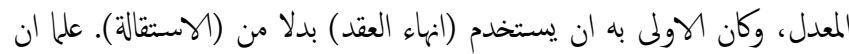

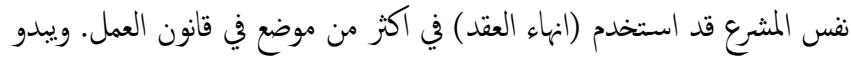

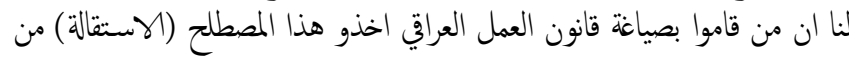

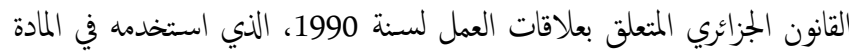

68

والفرق بين هذه الحالة (اي الاستقالة) والحالات التي اعطى فيها المشرع الحق

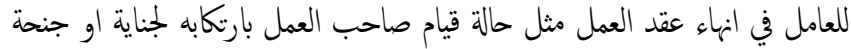

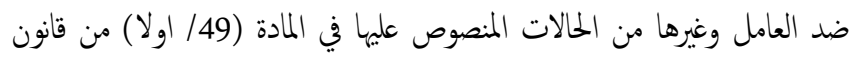

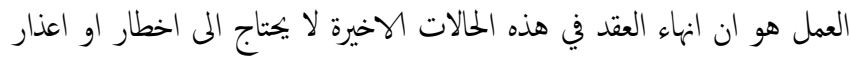

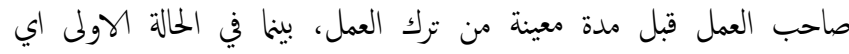

الاستقالة، فيجب عليه اخطار صاحب العمل قبل ثلاثين يوما من ترك العمل.

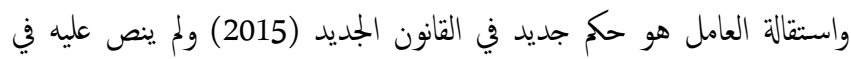

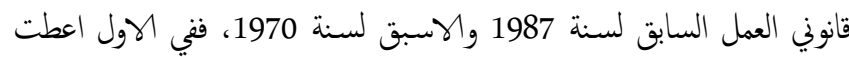

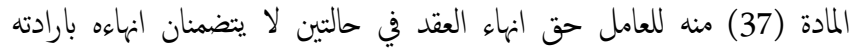

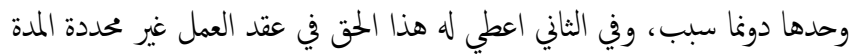

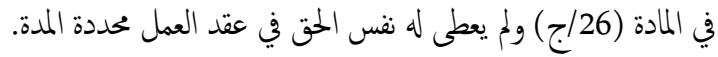

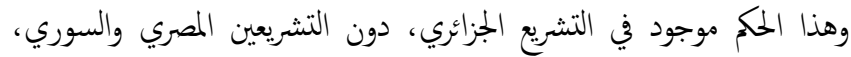

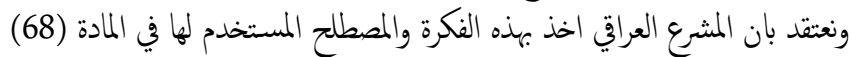
من التشريع المذكور.

ان الاستاذين كلا من الدكتورعدنان العابد والدكتور يوسف الياس (ص314)

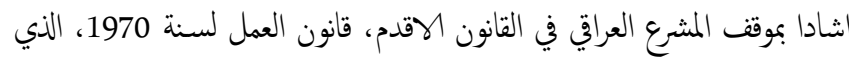

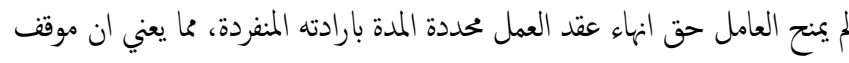

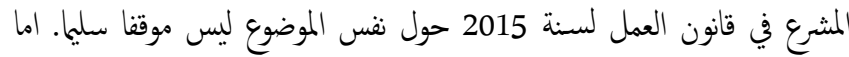

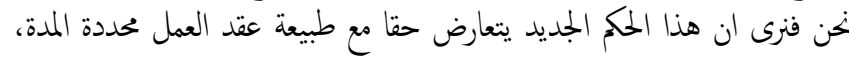

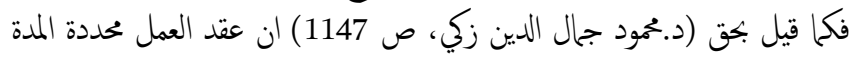

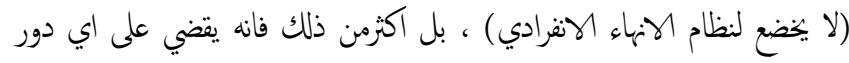

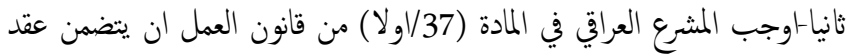

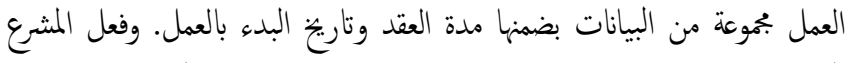

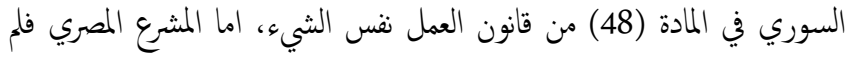

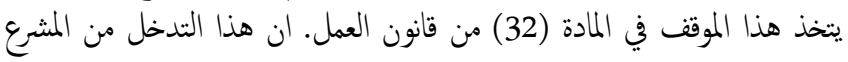

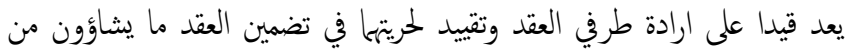

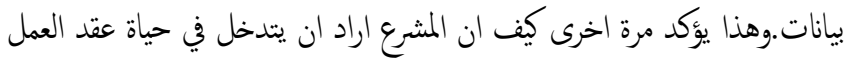
حتى في مرحلة ابرامه. ان الفلسفة وراء تدخل المشرع في مرحلة ابرام العقد، بالشكل الذي فصلنا فيه

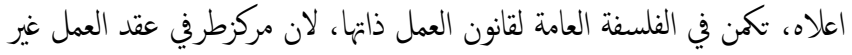

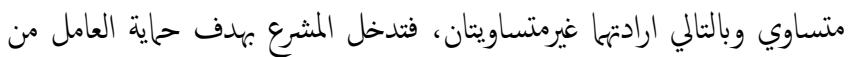

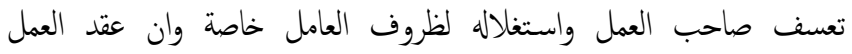

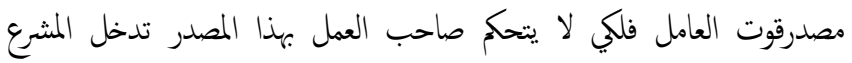
وفرض مثل هذه القيود على ارادة طرفيه.

\subsubsection{5.الفرع الثاني-دورالارادة في انهاء عقد العمل}

لا يلعب مبدا (العقد شريعة المتعاقدين) دوره في عقد العمل بالشكل الذي يلعبه

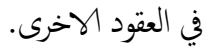
وقبل ان نبين حكم انهاء عقد العمل لابد ان نقول ان انهاء انهاء عقد العمل شيء وان انهان

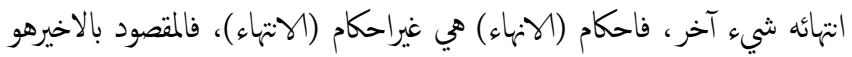

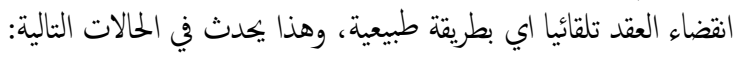

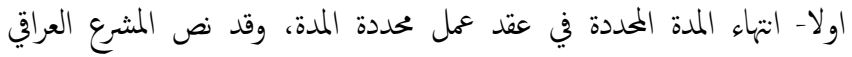

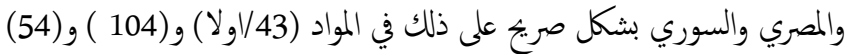

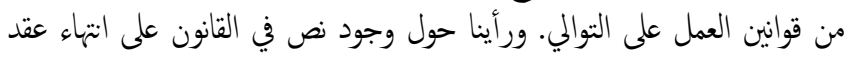

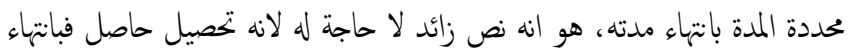

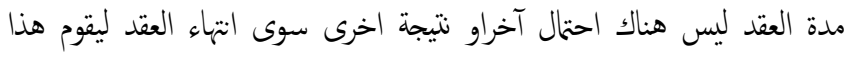
النص باستبعاده. ثانيا- الانتهاء من اداء العمل او تقديم المخدمة المتفق عليها في عقد عمل بتنفيذ إنداء

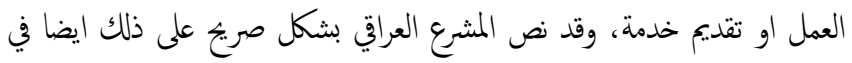

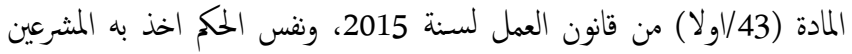

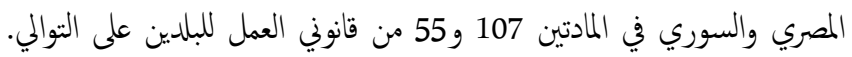

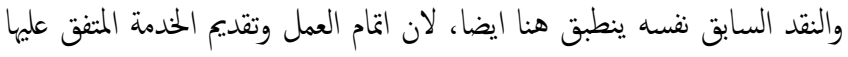

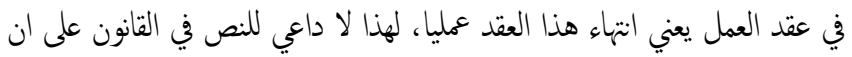
العقد ينتهي بانتهاء العمل او تقديم الخدمة.

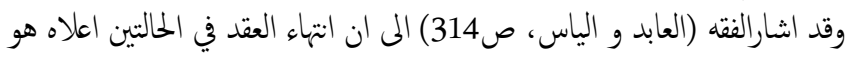

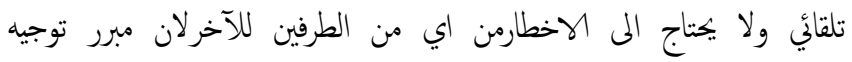

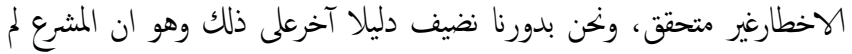

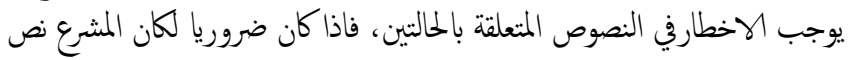

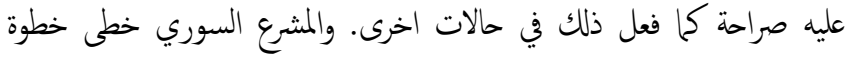

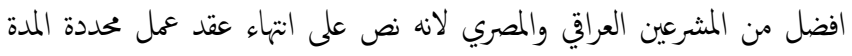

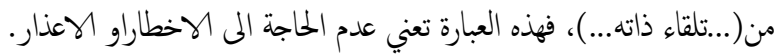

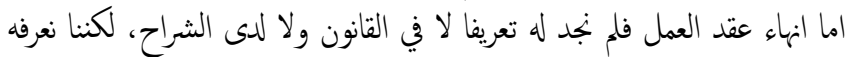

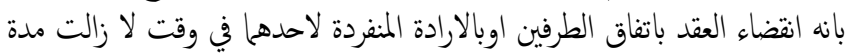


بالرجوع الى نصوص قانون العمل الخاصة بعقد العمل لم نجد نصا فيه يتضمن منح

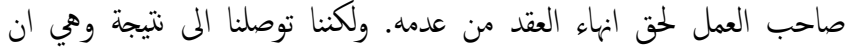
صاحب العمل لا يملك انهاء عقد العمل بارادته المنفردة، من خلاد العال الحقائق الاتية:

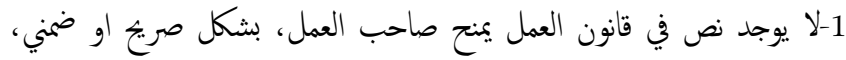

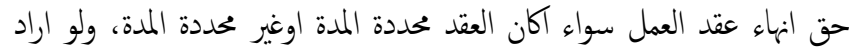

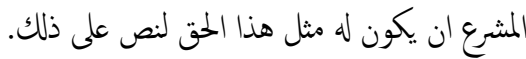

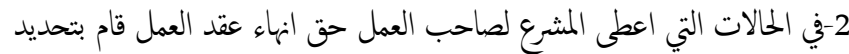

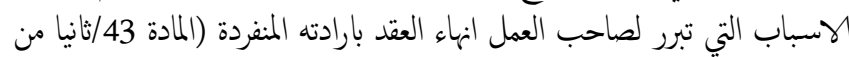

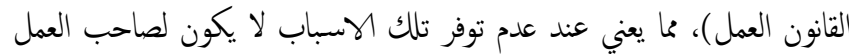

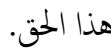
الا ان هناك حالة واحدة يحق لصاحب العمل انهاء عقد العمل فيها وهذه الحلالة

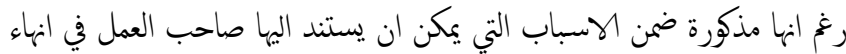

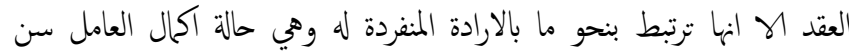

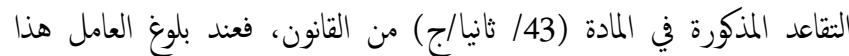

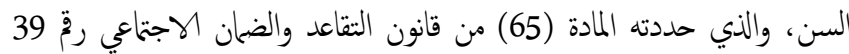

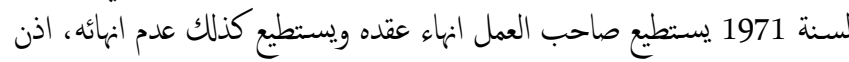
في الحالتين الامر متروك لارادته.

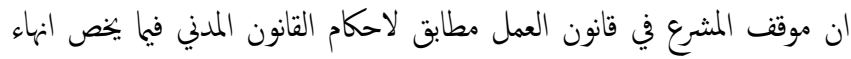

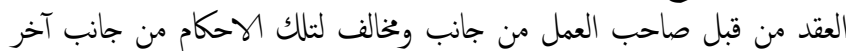
تبعا لنوع العقد وحسب التفصيل الآتي:

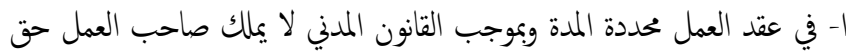

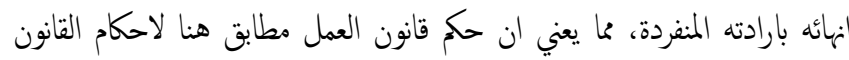

ب- في عقد العمل غير محددة المدة وبموجب القانون المدني يملك صاحب العمل حق انهائه بارادته المنفردة، مما يعني ان حكم قانون المدة وثمب العمل مخالف هنا لاحكام

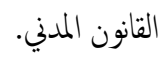

\section{6}

بعد دراسة دقيقة لموضوع المدة في عقد العمل في ظل احكام القانونين المدني

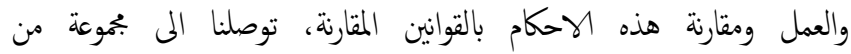
الاستنتاجات والتوصيات والتي نلخصها فيما يلي:

\section{6.1}

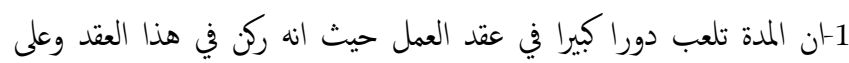
اساسها يتم تحديد انواع عقد العمل.

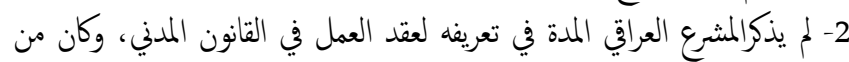

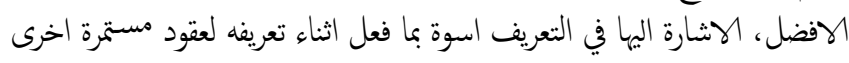
كقد الايجاروغيره. 3-ان عدم ذكر المدة في عقد العمل لا يبطله، فيستمرالى ان يقوم احد طرفيه بانهائه الحانه

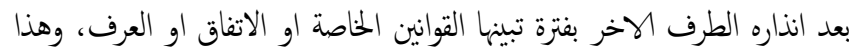

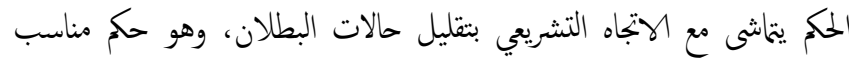

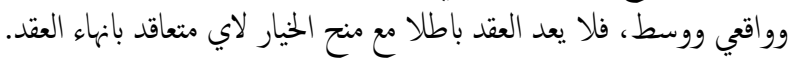

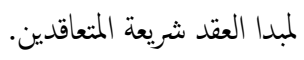

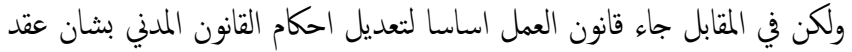

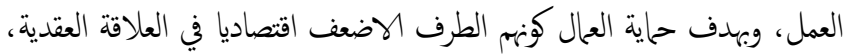

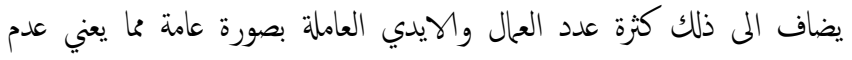

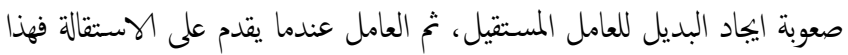

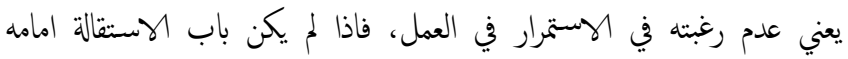

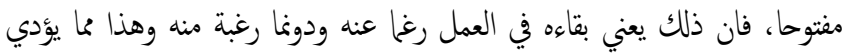

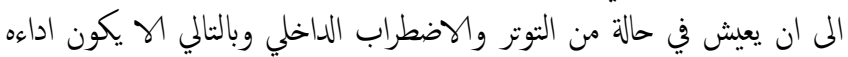

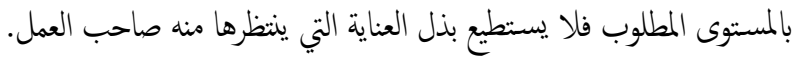

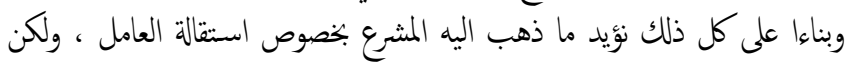

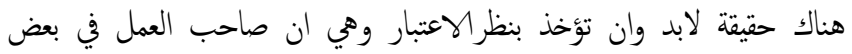

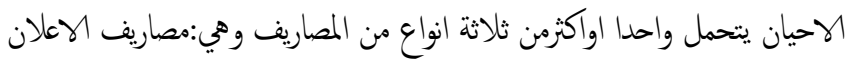

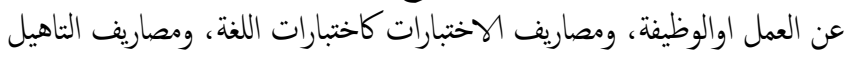

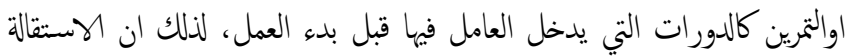

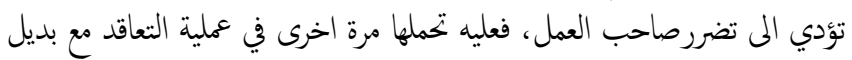

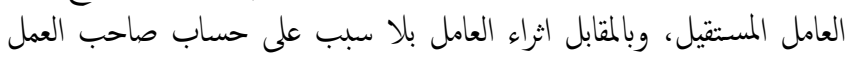

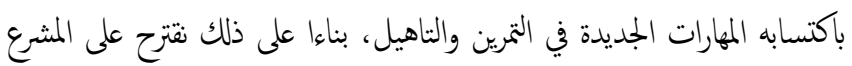

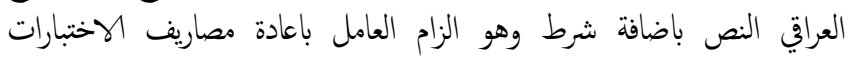

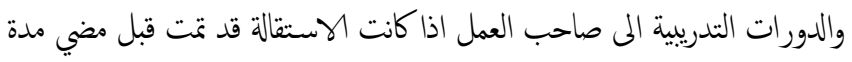

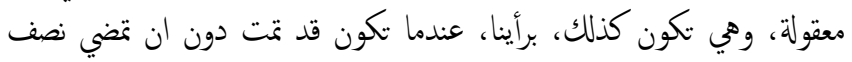

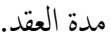

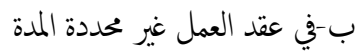

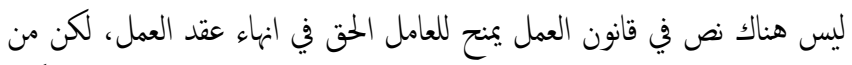

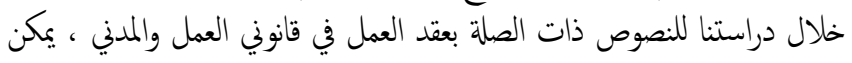

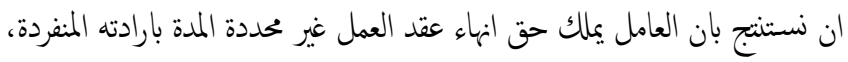
ودليلنا في ذلك هو:

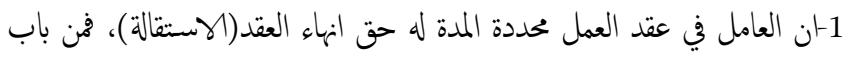

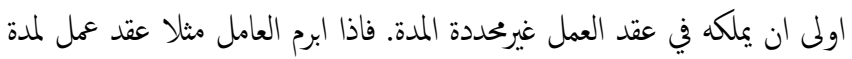

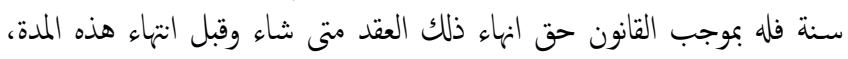

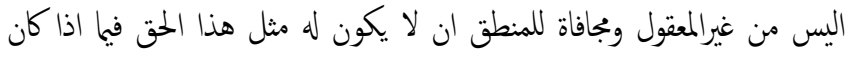

عقده لمدة غير محددة؟

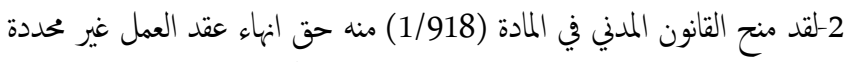

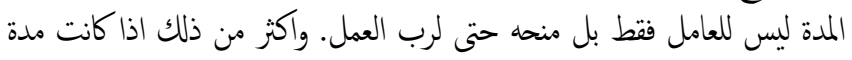

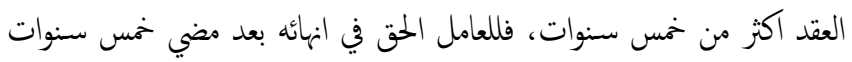

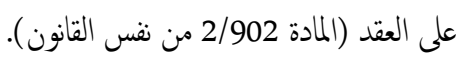

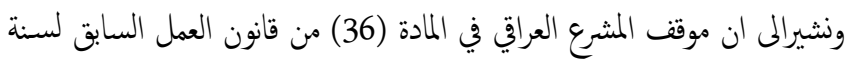

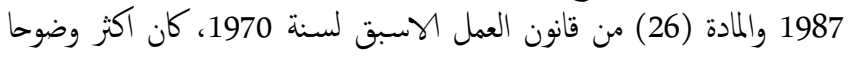

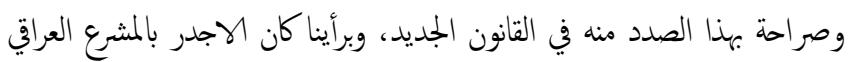

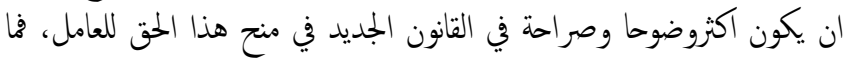

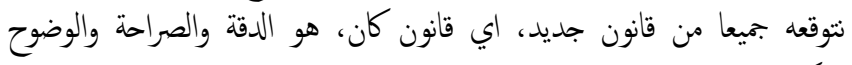

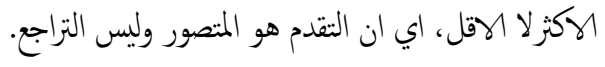

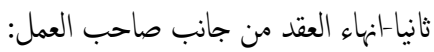




\section{2}

1-ان الفقرة (1) من المادة (918) من القانون المدني لا حاجة لها وزائدة لان الحكم

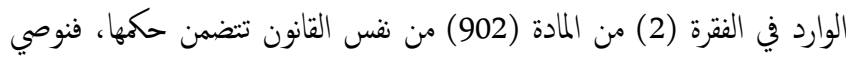

بحذفها. 2-رفع التناقض الموجود بين فقرتي المادة (924) من القانون المدني، فالاولى تقضي

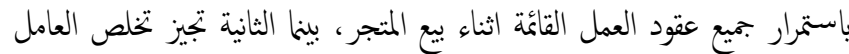
اورب العمل الجديد منها. 3-في الوقت الذي نشيد بموقف المشرع العراقي في قانون العمل الجديد لسنة المبا.

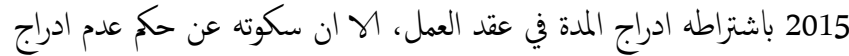

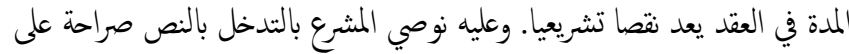

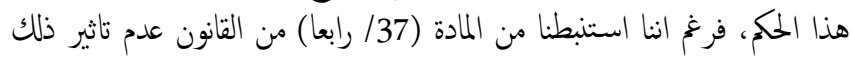

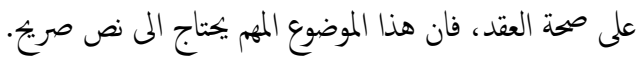

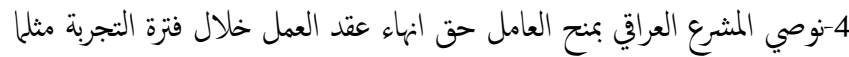

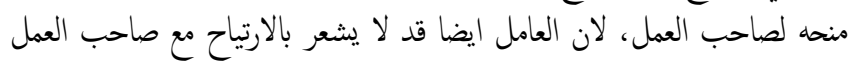
اوالعمل او ظروفه وكذلك اسوة بالمشرع السوري الذي منحه لكان لكليها.

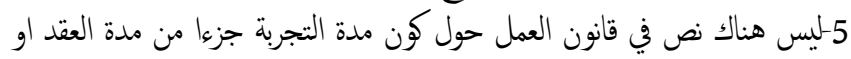

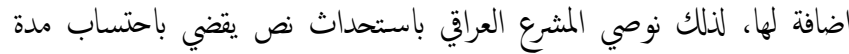

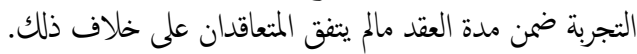

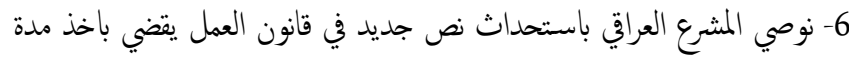

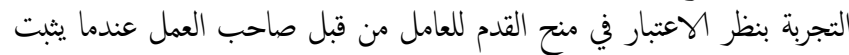
العامل في العمل بعد انتهاء فترة التجربة.

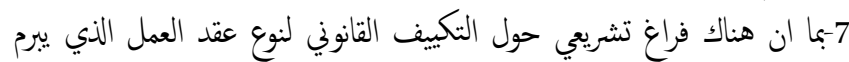

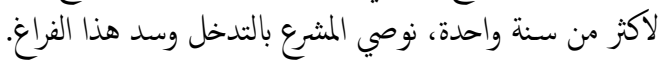

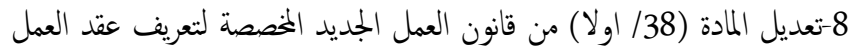

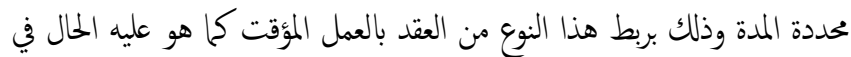

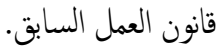
9- تعديل المادة (38/ رابعا) في قانون العمل بجيث يقضي نصها بتحول العقد الى الى

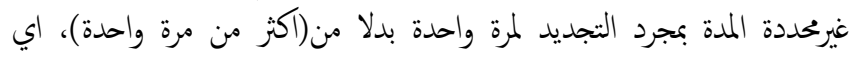

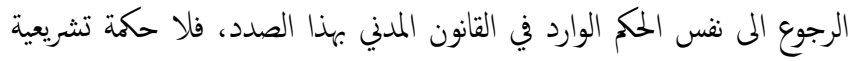

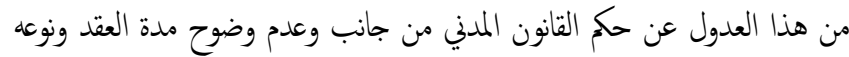
بعد تجديده للمرة الواولى من جانب آخر.

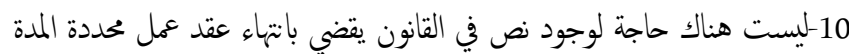

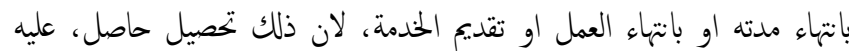

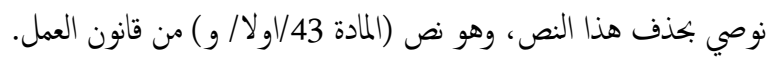

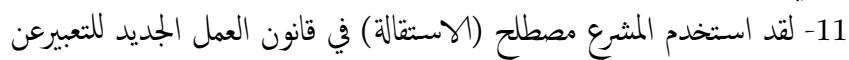

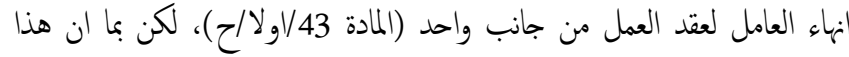

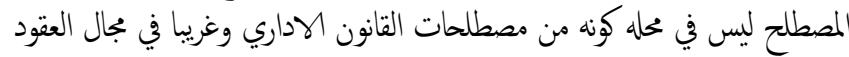

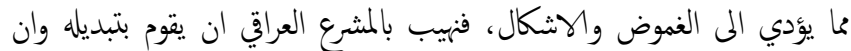

$$
\text { يستخدم (انهاء العقد) بدلا من (الاستقالة العنالة). }
$$

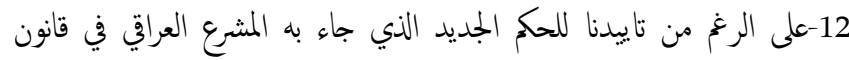

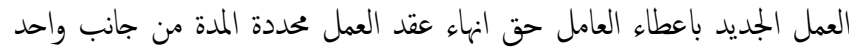

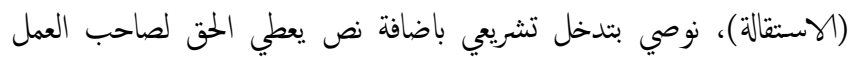

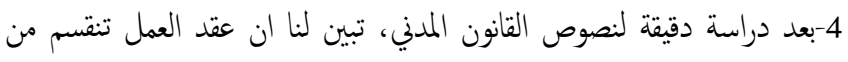

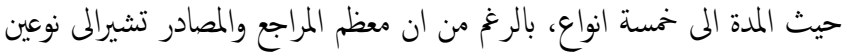
منه فقط. 5- لكي يكون عقد العمل محددة المدة لابد من تعيين وقت انتهائه اضافة الى المدة،

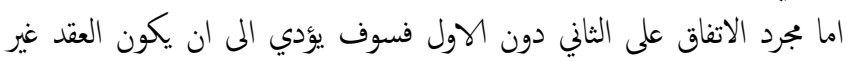

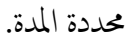
6- يتمتع الطرفان في عقد العمل محددة المدة بحرية اكبرمقارنة بالعقد غير محددة المدة، وفي النوع الثاني تتغلب فكرة استقرارالرابطة العقدية. وتميل القوانين المقارنة الى عقود العمل غير محددة المدة وذلك حاية للعامل وحفاظا على مورد رزقه.

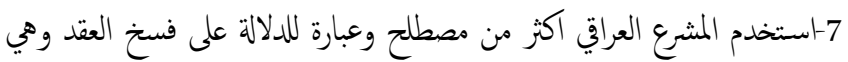

$$
\text { (الانهاء) و(الفنخ) و(التخلص منه). }
$$

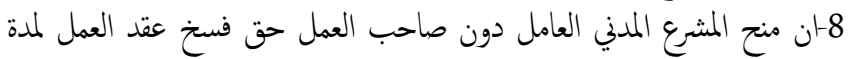

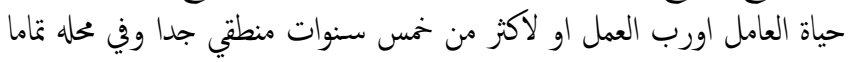
نظرا لاختلاف مركزها الاقتصادي.

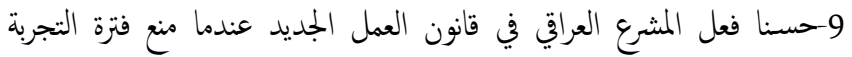

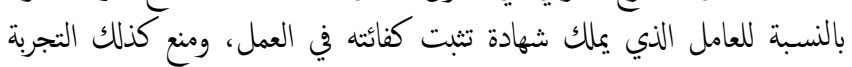
لاكثر من مرة واحدة لدى نفس صاحب العمل.

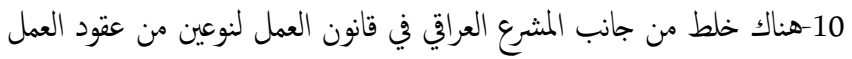

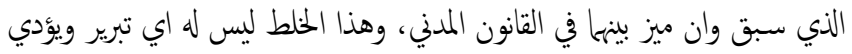

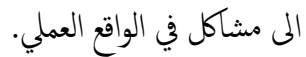

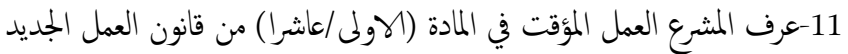
لكنه لم يتطرق الى هذا النوع من العمل في ثنايا القانون.

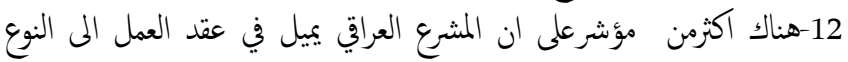

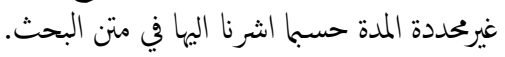

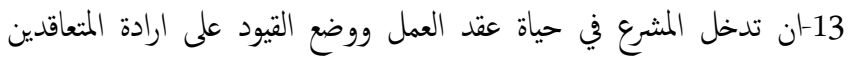

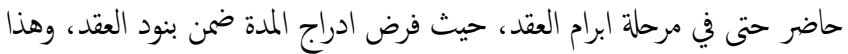

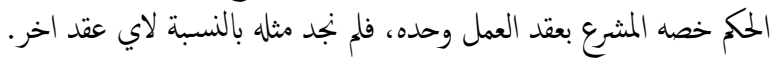

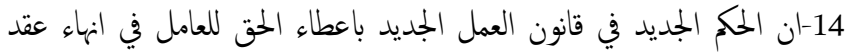

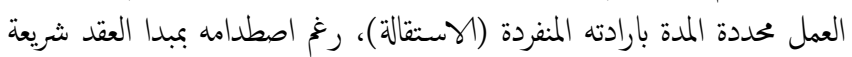

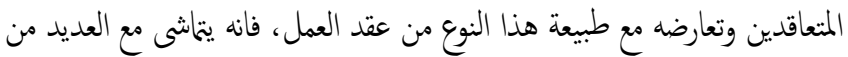
حقائق قانونية وواقعية ذكرناها بالتفصيل في موقعها.

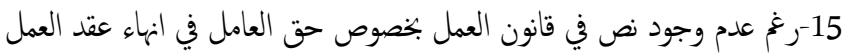

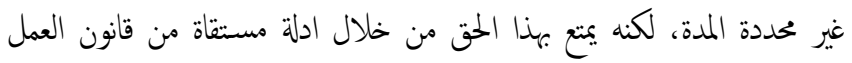

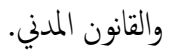
16- في ظل قانون العمل لا يملك صاحب العمل حت انهاء عقد العمل(بنوعيه

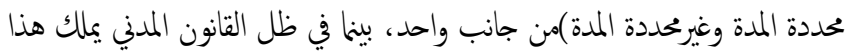

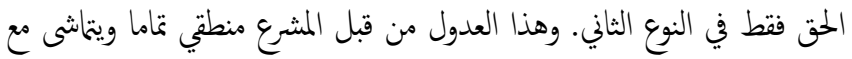

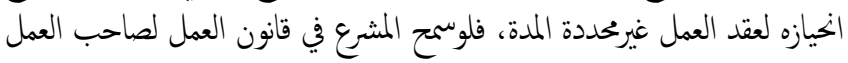

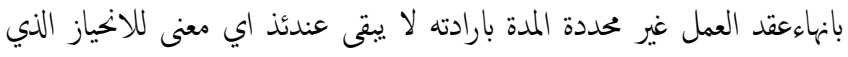

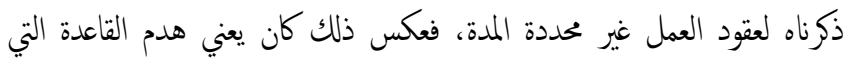
وضعها والتي تقضي بعدم جوازتحديد مدة العقد في الاععال ذات المات الطبيعة المستمرة (المادة 38/ثانيا من قانون العمل). 


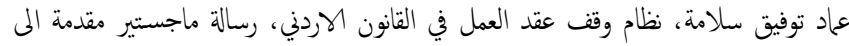
جامعة الشرق الووسط للدراسات العليا، عمان، 2009.

د.قدري عبد الفناح الشهاوي، موسوعة قانون العمل-القانون رقّ 12 لسنة 2003- منشاة

$$
\text { المعارف بالاسكندرية، بدون سنة طبع. }
$$

د.بمحُمَحسين منصور، قانون العمل، ط1، منشورات الحلبي الحقوقية، بيروت، 2010.

د.محمود جال الدين زكي، عقد العمل في القانون المصري (التقنين المدني، قانون العمل الجديد،

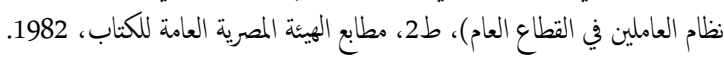

د.مصطى اممد الزرقاء، شرح القانون المدني السوري، نظرية الالتزام العامة،1-المصادر (العقد

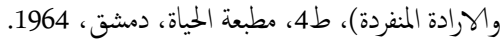

د.منيرمحود الوتري، القانون، ط2، مطبعة الجاحظ، بغداد، بدون سنة طبع.

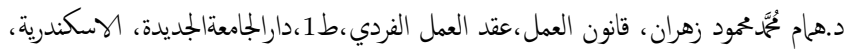
بدون سنة طبع.

د.وحيد الدين سوار، الاتجاهات العامة في القانون المدني الاردني دراسة موازنة بالققه الهسلاي الماتي

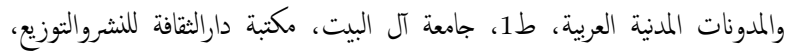

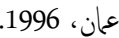

د.يوسف الياس، الوجيز في شرح قانون العمل رقز 71 لسنة 1987، وزارة النعليم العالي والبحث العلمي، البرجيز في شرح.

\section{ثانيا-البحوث}

د.احمد زكي بدوي، التشريعات الخاصة بحاية القوى العاملة، بحث منشورضمن الحلقة الدراسية

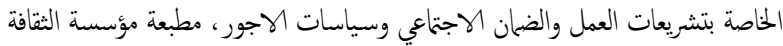

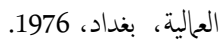

د.بلعبدون عواد، عقود العمل محددة المدة على ضوء الاجتهاد القضائي الجزائري، بحث منشور

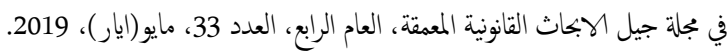

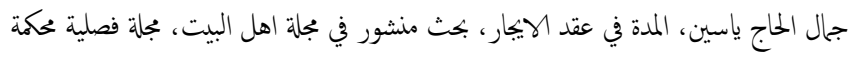
تصدرعن جامعة اهل البيت، العدد 13، السنة السادسة، ايلول، 2012.

د.فراس يوسف الكساسبة، مدى انسجام حالات اعفاء صاحب العمل من الاشعارعند انهائه

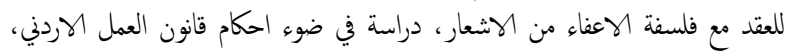

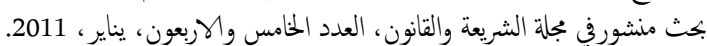

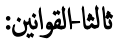

القانون المدني المصري رة 131 لسنة 1948 المعدل.

القانون المدني السوري رخ 84 لسنة 1949.

القانون المدني العراقي رقٌ 40 لسنة 1951.

قانون المدمة المدنية رق 24 لسنة 1960.

قانون ايجارالعقارر 87 لسنة 1979 المعدل.

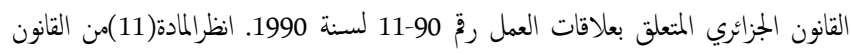

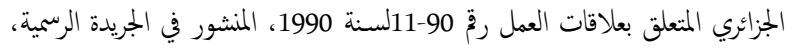
السنة 27، العدد17، الصادر بتاريخ 25/ابريل(نيسان)/1990.

قانون انضباط موظني الدولة رק 14 لسنة 1991 المعدل.

قانون العمل المصري رق 12 لسنة 2003. قانون العمل السوري رڤٌ 17 لسنة 2010.
بالرجوع على العامل بكاريف الاختبارات والدورات التدريبية ان وجدت اذا كانت الاستقالة قبل منتصف مدة العقد.

-

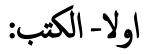

د.بدر جاسم اليعقوب، انهاء عقد العمل غير محدد المدة في القانون الكويتي (دراسة مقارنة)،

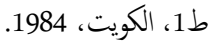

د.توفيق حسن فرج، النظرية العامة للالتزام في مصادر اللالتزام مع مقارنة بين القوانين العربية،

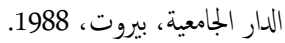

د.حسن الذنون، النظرية العامة للالتزام، ج1، مصادرالاتززام، 1946.

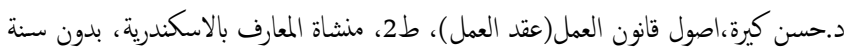
طبع. د.سعيد مبارك ود.طه الملا حويش ود.صاحب عبيد الفنلاوي، الموجزفي العقود المسماة، البيعالاييار - المقاولة، المكتبة القانونية، بغداد، 2007.

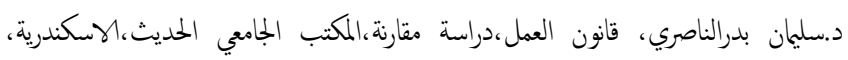
.2010

د.شاب توما منصور، شرح قانون العمل رق 151 لسنة 1971، ط4، دارالطبع والنشرالاهلية، بغداد، شرح 1971.

د.صادق مهدي السعيد، العمل وتشغيل العهال والسكان والقوى العاملة، الكتاب الوول،

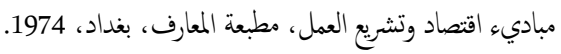

د.صبا نعان رشيد الويسي، وقق عقد العمل وتطبيقاته، منشورات الحلبي الحقوقية، ط1، .2012

عبدالباقي البكري وزهير البشير، المدخل لدراسة القانون، بيت الحكمة، دون سنة طبع.

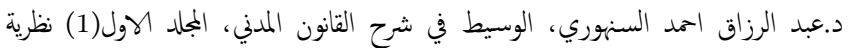

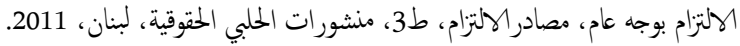

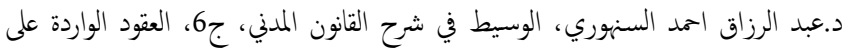

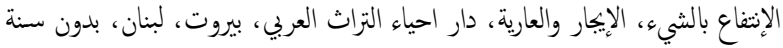
الطبع.

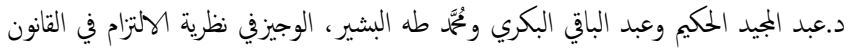

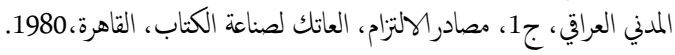

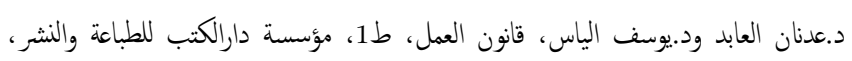

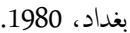
د.عصمت عبد المجيد بكر، النظرية العامة للالتزامات، ج1، مصادرالاتززام، ط1، مطبوعات جامعة جيهان المخاصة، 2011.

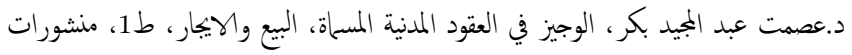

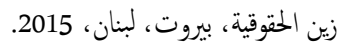

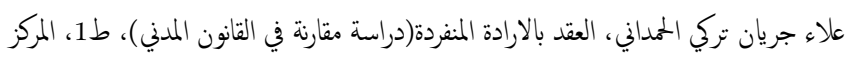
العربي للنشروالتوزيع، القاهرة، الماردي، 2019.

د.عماد حسن سلمان، شرح قانون العمل الجديد رقٌ (37) لسنة 2015، دار السنهوري،

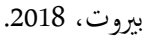




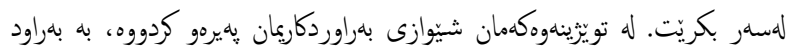

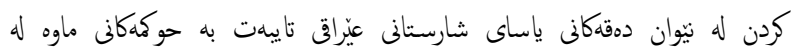

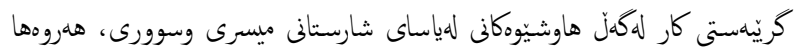

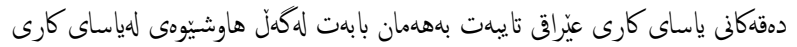

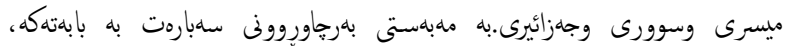

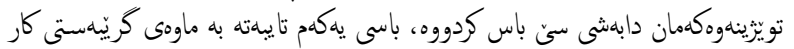

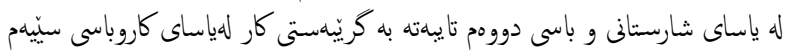

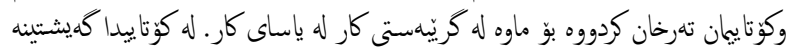

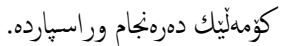

قانون العمل العراقي رقٌ 37 لسنة 2015.

يوخته

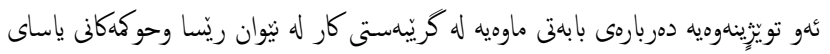

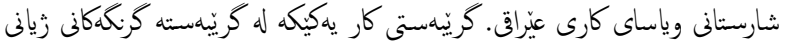

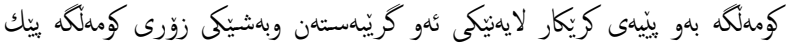

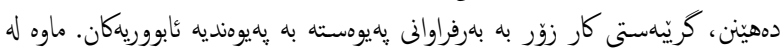

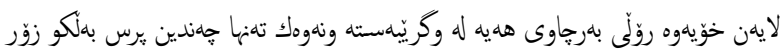

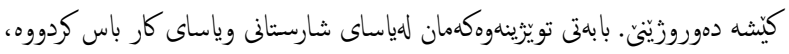

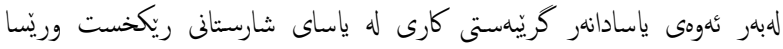

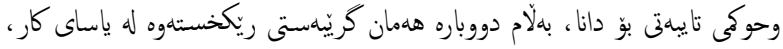

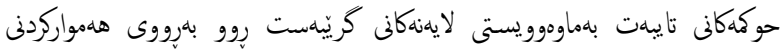

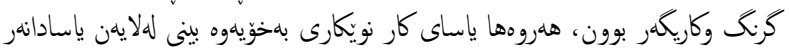

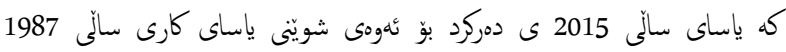

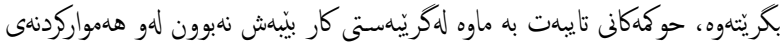

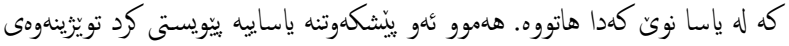

